Canadian Journal of Applied Linguistics

Revue canadienne de linguistique appliquée

\title{
The Suitability of French Immersion for Allophone Students in Saskatchewan: Exploring Diverse Perspectives on Language Learning and Inclusion
}

\author{
Stephen Davis, Susan Ballinger and Mela Sarkar
}

Volume 22, Number 2, 2019

URI: https://id.erudit.org/iderudit/1063773ar

DOI: https://doi.org/10.7202/1063773ar

See table of contents

\section{Publisher(s)}

University of New Brunswick

ISSN

1920-1818 (digital)

Explore this journal

Cite this article

Davis, S., Ballinger, S. \& Sarkar, M. (2019). The Suitability of French Immersion for Allophone Students in Saskatchewan: Exploring Diverse Perspectives on Language Learning and Inclusion. Canadian Journal of Applied Linguistics / Revue canadienne de linguistique appliquée, 22(2), 27-63.

https://doi.org/10.7202/1063773ar

\section{Article abstract}

French immersion programs in Saskatchewan have traditionally served to further the goals of additive bilingualism between Canada's two official languages, French and English. Whereas these programs have historically consisted of predominantly Anglophone populations, recent trends in immigration have contributed to the increasingly diverse linguistic backgrounds of students throughout the province. The motivation, family support, and high academic achievement of allophone students learning French as an additional language have been documented extensively in Canada (Dagenais \& Jacquet, 2000; Mady, 2013, 2014, 2015). Nevertheless, allophone students often do not benefit from the same access to second language education programs as their Anglophone and Francophone peers; indeed, such learners are sometimes excluded from French immersion programs on the basis of their lack of English language proficiency (Roy, 2015). Through Likert-scale surveys and semi-structured interviews, this mixed-methods research explored the perceived suitability of French immersion for allophone students by examining the perspectives of parents and educators in several schools in Saskatoon, Saskatchewan. This study will share the triangulated findings of the research, discuss the suitability of French immersion programs for allophone students, and provide recommendations for the future of such programs in Saskatchewan.
Copyright (c) Stephen Davis, Susan Ballinger, Mela Sarkar, 2019

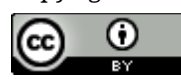

This document is protected by copyright law. Use of the services of Érudit (including reproduction) is subject to its terms and conditions, which can be viewed online.

https://apropos.erudit.org/en/users/policy-on-use/ 


\title{
The Suitability of French Immersion for Allophone Students in Saskatchewan: Exploring Diverse Perspectives on Language Learning and Inclusion
}

\author{
Stephen Davis \\ Saskatoon Public Schools \\ Susan Ballinger \\ McGill University \\ Mela Sarkar \\ McGill University
}

\begin{abstract}
French immersion programs in Saskatchewan have traditionally served to further the goals of additive bilingualism between Canada's two official languages, French and English. Whereas these programs have historically consisted of predominantly Anglophone populations, recent trends in immigration have contributed to the increasingly diverse linguistic backgrounds of students throughout the province. The motivation, family support, and high academic achievement of allophone students learning French as an additional language have been documented extensively in Canada (Dagenais \& Jacquet, 2000; Mady, 2013, 2014, 2015). Nevertheless, allophone students often do not benefit from the same access to second language education programs as their Anglophone and Francophone peers; indeed, such learners are sometimes excluded from French immersion programs on the basis of their lack of English language proficiency (Roy, 2015). Through Likert-scale surveys and semi-structured interviews, this mixed-methods research explored the perceived suitability of French immersion for allophone students by examining the perspectives of parents and educators in several schools in Saskatoon, Saskatchewan. This study will share the triangulated findings of the research, discuss the suitability of French immersion programs for allophone students, and provide recommendations for the future of such programs in Saskatchewan.
\end{abstract}

\section{Résumé}

L'immersion française renvoie à une approche pédagogique qui a pour but la préparation des élèves à travailler et à vivre en français tout en leur permettant de développer des compétences dans les deux langues officielles du Canada. Bien que, historiquement, les élèves anglophones nés au Canada aient été ceux qui ont le plus fréquenté l'immersion française en Saskatchewan, on observe une hétérogénéisation de la population d'élèves inscrits dans ce type de programme, grâce à une augmentation récente de l'immigration dans la province qui contribue à la diversité grandissante tant sur le plan linguistique que culturel. Plusieurs études ont examiné la motivation des élèves allophones envers l'apprentissage du 
français au Canada, leurs capacités d'acquérir le français et l'anglais simultanément, et l'importance que leurs familles accordent au multilinguisme (Dagenais et Jacquet, 2000 ; Mady, 2013, 2014, 2015). Malgré leur succès bien documenté en immersion, les élèves allophones sont parfois exclus de ces programmes à cause de leurs niveaux insuffisants d'anglais (Roy, 2015). Cette recherche vise à explorer divers discours au sujet des élèves allophones en immersion française. Spécifiquement, l'étude adopte une méthodologie mixte, menée par l'entremise de questionnaires et d'entretiens, afin d'examiner les perspectives de parents et d'éducateurs, provenant de plusieurs écoles de Saskatoon, en Saskatchewan. Cette étude présentera les résultats quantitatifs et qualitatifs de la recherche, ainsi que certaines recommandations pour les programmes d'immersion dans le but d'offrir une éducation équitable à une population diversifiée.

\section{The Suitability of French Immersion for Allophone Students in Saskatchewan: Exploring Diverse Perspectives on Language Learning and Inclusion}

The recent history of Canada's linguistic identity has been characterized by a discourse of dualism between the country's two official languages, English and French (Haque, 2012). This ideology has been shaped by the revised Official Languages Act, which includes a commitment to "enhance opportunities for all to learn both English and French" (Government of Canada, 1985). Thus, language education initiatives throughout Canada have traditionally offered English instruction for students whose first language is French (Francophones) and French instruction for students whose first language is English (Anglophones; Galiev, 2013). However, developments in immigration have transformed the linguistic demographics of the country; indeed, $20.6 \%$ of Canadian students today speak a first language that is neither English nor French (Statistics Canada, 2014). Such students are hereafter referred to as allophones. Thus, educators and policy developers must adapt to the increasingly diverse demographics of Canadian schools. In light of the rapidly changing student populations and the extent to which educational policy has often overlooked allophone learners in language planning, the question of whether French immersion is an appropriate program for such students becomes critical. The purpose of the present study is to examine the perspectives of educators and parents regarding the suitability of French immersion for allophone students in Saskatchewan.

\section{French Language Education in Saskatchewan}

French language education in Saskatchewan has faced significant challenges throughout the history of the province and indeed before its inception, for Francophones and language learners alike. Provincial legislation did not permit French instruction until 1915, and radical organizations in Saskatchewan, such as the Ku Klux Klan, opposed the use of French in schools (D'Almeida, 2006). Subsequently, the Federal government adopted French and English as Canada's two official languages in 1969, and the ensuing Canadian Charter of Rights and Freedoms in 1982 established the right to minority language education (D'Almeida, 2006). With respect to French education for additional language learners, Saskatchewan's first French immersion program began in the city of Saskatoon, and subsequently spread throughout the province (Reeves, 2006). Currently, there are 85 French immersion schools in Saskatchewan, and demand for the program continues to rise (Bonjour SK, 2018). Whereas the most common format of French 
immersion in Saskatchewan entails beginning in Kindergarten or Grade 1, some school boards offer late French immersion for students starting to learn French in Grade 6 and 7 (Saskatchewan School Boards Association, 2017). Notwithstanding the different starting ages noted above, French immersion programs share a goal of educating learners of diverse linguistic backgrounds, and prior exposure to the French language is neither necessary for enrolment, nor required for success in such programs.

\section{Languages in Saskatchewan}

Most residents of Saskatchewan are Anglophones (82.4\%), while Francophones make up only $1.4 \%$ of the population. Only $4.7 \%$ of Saskatchewan residents report speaking English and French well enough to carry on a conversation in both languages (Government of Saskatchewan, 2017). French is a clear minority language and officiallanguage bilingualism rates remain low throughout the province.

Although Saskatchewan receives fewer immigrants and refugees than some provinces in Canada, the number of newcomer allophones is rising considerably, which contributes to the growing linguistic diversity throughout the province. As of 2016, 14.5\% of the province's residents claim a first language other than English or French, up from $12.7 \%$ in 2011 (Government of Saskatchewan, 2017). Saskatchewan received 11,826 new immigrants in 2014. The five most common source countries, in order of number of immigrants, were the Philippines, India, China, Ukraine, and Pakistan. Tagalog (26\%), Chinese (8\%), Punjabi (8\%), English (8\%), and Gujarati (6\%) were the five most common newcomer mother tongues (Government of Saskatchewan, 2014).

\section{Literature Review}

\section{Overview of French Immersion}

French immersion began in St. Lambert, a predominantly English-speaking suburb of Montréal, Québec, in 1965, to respond to the concerns of Anglophone parents who believed that their children were unprepared to compete in the increasingly Frenchdominant workforce of the province (Lambert \& Tucker, 1972). Lyster (2008) reported that French immersion students obtain content knowledge that is equivalent to that of nonimmersion learners studying in English, and Lindholm-Leary and Genesee (2014) found that immersion students develop English abilities similar to or greater than those of learners in regular English programs. Additionally, immersion students consistently outperform learners in core language programs in terms of reading, writing, listening, and speaking (Genesee \& Lindholm-Leary, 2013). Immersion has also served an important political purpose; federal and provincial governments have embraced the program as a means to unite Anglophones and Francophones through official-language bilingualism. French immersion therefore embodies not only a pedagogical shift toward content-driven language instruction, but also an endeavour to increase social cohesion between Anglophones and Francophones in Canada.

French immersion programs vary with respect to starting ages and time spent in the target language, but share several core tenets. Johnson and Swain (1997) listed the following eight common factors that characterized immersion programs in Canada: first, the second language is the medium of instruction; second, the immersion curriculum 
parallels the first language curriculum; third, curricular support is offered for the first language; fourth, the program aims for additive bilingualism; fifth, exposure to the second language is generally limited to the classroom; sixth, students begin the program with limited levels of second language proficiency; seventh, the teachers are bilingual; and eighth, the classroom culture is that of the first-language community.

Although the above traits were representative of immersion programs 20 years ago, many of the descriptors are inaccurate in the current Canadian context. In their revision of the key features of immersion, Swain and Lapkin (2005) noted that the third criterion (support is offered for first language development) was only true for Anglophones, as allophones often do not receive instruction in their first languages. The eighth criterion (the classroom culture is that of the first-language community) is also erroneous; the increased ethnic and linguistic diversity in immersion classrooms reflects complex, heterogeneous populations, which are not typically included in immersion classroom culture. More recently, Roy (2008) and Mady (2015), among others, urged language educators to recognize the increasingly diverse demographics of Canadian schools today.

\section{French Language Education Policy for Allophone Students}

Two policy documents, titled The Next Act: New Momentum for Canada's Linguistic Duality (Canada Privy Council Office, 2003) and The Roadmap for Canada's Linguistic Duality 2008-2013: Acting for the Future (Department of Canadian Heritage, 2013), addressed the federal government's goal of doubling the number of secondary graduates who are bilingual in both official languages. However, Mady and Turnbull (2010) noted that in "English Canada, immigrants must learn English, but their access to also learn French at school is not guaranteed by Federal policy documents" (p. 5). Indeed, Federal government documents strongly support allophone students learning one of Canada's official languages, but there is minimal policy in place to support their learning of both French and English (Galiev, 2013).

Similarly, official-language bilingualism for allophone students is seldom discussed at the provincial or territorial level, which Mady and Black (2012) argued has led to inconsistencies in allophones' access to French immersion. There is also significant discrepancy amongst provinces and territories regarding whether learning French is mandatory or optional for all students. In Saskatchewan, students are not required to study French or any language in addition to English, and no policy exists regarding the inclusion or exclusion of allophone learners. Mady (2007) also noted that there was no English as an additional language (EAL) curriculum in the province, arguing that the "lack of such a curriculum may be due in part to the low number of foreign-born residents" (p. 741). Despite increased immigration to Saskatchewan, no such curriculum exists today.

\section{Perspectives of French Language Educators}

In addition to the creation and implementation of language policies for allophone students, it is important to consider the perceptions of teachers and principals regarding the suitability of French language programs for such learners. Lapkin, MacFarlane, and Vandergrift (2006) conducted a survey examining the beliefs of 1,305 teachers of French as an additional language throughout Canada and found that participants considered student diversity among the greatest challenges they faced as educators, specifically noting the 
growing presence of allophones in the classroom. Several teachers indicated that immersion was too difficult for allophones and that they would instead recommend core French for such students (Lapkin et al., 2006). Subsequently, Mady (2011) found that immersion teachers espoused less inclusive views regarding allophone students than did core French teachers. More recently, Mady and Masson (2018) conducted surveys and interviews with principals of immersion schools. They found that principals held divergent views regarding their roles as gatekeepers of immersion, and disagreed over whether allophones should attain a high level of English proficiency before beginning the program. This study is particularly valuable in light of the dearth of research examining French language educators' perspectives concerning allophone students. However, as Mady and Turnbull (2012) noted, "the few studies that exist have almost all been completed in Ontario or in larger urban centers where many immigrants live" (p. 134).

In a study examining the experiences of French as an additional language teacher candidates throughout the country, Mady and Arnett (2016) documented pre-service teachers' lack of preparation to meet the needs of allophone learners. Although some teacher candidates did learn about allophone students in their university courses,

the vast majority (7/9 or $78 \%$ ) could not access any scientific knowledge about these students and their learning needs to support the work in the practicum, thus revealing a disconnect between the content of their teacher education program and the classroom reality. (p. 87)

The extent to which some teacher education programs appear to neglect the important reality of student diversity should be a concern amongst stakeholders in the education of French language teachers.

\section{Allophone Family Motivation}

Several studies have documented the high motivation of many allophone students to learn both English and French in Canadian schools. Mady (2010) researched the motivation of Canadian-born secondary students and recent newcomers to study in core French programs and found that newcomer allophone students often considered official-language bilingualism an essential element of Canadian identity, whereas this perspective was less prevalent amongst their Canadian-born peers. Subsequently, Carr (2013) noted that many allophone parents believed French-English bilingualism was important to Canadian identity, due to the official status of the languages.

Researchers have also found that allophone students and families pursue FrenchEnglish bilingualism because they are more likely than their Anglophone counterparts to believe that official-language bilingualism will provide social and employment opportunities in the future (Dagenais \& Berron, 2001; Dagenais \& Jacquet, 2000; Mady, 2003). Thus, allophone students and their families tend to be highly motivated to learn both French and English in Canada, both for intrinsic reasons regarding identity and for extrinsic reasons pertaining to economic opportunity. 


\section{Allophone Language Learning}

Researchers have demonstrated that the widespread belief that allophone students will find the simultaneous acquisition of French and English overwhelmingly difficult is unfounded. Bérubé and Marinova-Todd (2012) compared three student demographics in French language programs - English monolingual learners, multilingual learners with an alphabetic first language, and multilingual learners with a logographic first language - and concluded that the Anglophones had no advantages over the multilingual students with alphabetic first languages. Additionally, Carr (2007) found that allophone students studying French and English simultaneously developed significantly higher English language abilities than those who were only studying English.

Allophone students seem to have certain advantages for learning French in comparison with their Anglophone counterparts. For instance, Izquierdo and Collins (2008) observed that Spanish-speaking French immersion students demonstrated a greater understanding of passé composé and imparfait verb tenses than their Anglophone counterparts. Mady (2007) reported that the French language skills of immigrant allophone students were stronger than those of Canadian-born students despite the fact that the allophones had experienced significantly less instructional time. More recently, Mady (2015) documented stronger French language proficiency amongst newcomer allophone students in French immersion compared to Canadian-born Anglophone and Canadian-born multilingual classmates, thereby advancing the notion of an advantage not only for allophone learners in general, but for newcomer allophone students in particular. In light of previous research, the language backgrounds of allophone students should not be viewed through a lens of deficiency with respect to language learning (García, 2002). Rather, such students have distinct advantages in French language programs compared to their Anglophone classmates.

\section{Methodology}

\section{Research Questions}

The purpose of the wider research project on which the present study is based was to examine the diverse perspectives of educators regarding the suitability of French immersion programs for allophone students in Saskatchewan. Specifically, the two research questions relevant for this portion of the study were:

1. What are the perspectives of educators and parents concerning the suitability of French immersion for allophone students in Saskatchewan?

2. What are the perspectives of educators and parents regarding the gatekeeping role that educators should play in French immersion programs in Saskatchewan?

To the extent that the study employed surveys and interviews simultaneously, the

methodological framework of this research was a convergent parallel methods design (Creswell, 2014). The rationale for this design was that the surveys would generate global, quantitative data from larger populations of the stakeholder groups - namely, French immersion educators and allophone parents-whereas the interviews would enable a more thorough analysis of the experiences of smaller samples of the populations. 


\section{Survey Methods}

The present study employed online surveys to generate data reflecting the perspectives of participants regarding the suitability of French immersion for allophone students in Saskatchewan. To this end, the researchers recruited educators and allophone parents from a school board in Saskatoon, Saskatchewan. The questionnaire for teachers and principals was sent via email and completed by 56 participants, while the questionnaire for parents was completed by 23 participants. The surveys included the following definitions to ensure a common understanding of terminology: "In this survey, the term 'Anglophone' refers to a student whose first language is English, whereas the term 'allophone' refers to a student whose first language is neither English nor French." The questionnaires consisted of several demographic questions followed by 20 multiple-choice questions for which participants were asked to select one of five possible Likert-scale responses. Additionally, each survey item included a comment box in which participants could elaborate on their answers. The researchers triangulated the quantitative and qualitative survey results with the qualitative interview results in order to analyze patterns and themes in the findings.

\section{Interview Methods}

In concert with the surveys, the researchers conducted 50 semi-structured, audiorecorded interviews with survey participants. They interviewed 43 teachers and principals in their respective schools, with the exception of one teacher who was interviewed via Skype. Conversely, the seven interviews with allophone parents occurred in a variety of settings, including participants' homes, their children's schools, and restaurants. Six elementary schools offering French immersion programs were represented in both the survey and interview data. All interviews were transcribed in full and analyzed using NVivo, and all participants were given pseudonyms. As per the nature of a convergent parallel mixed-methods study, the researchers analyzed the survey findings and the interview data concurrently. Specifically, they used descriptive statistics to analyze the quantitative data from the questionnaires and employed thematic coding to interpret the qualitative data that emerged from survey comments and interview responses.

\section{Results: Educators' Perspectives}

\section{Demographic Information}

In the first demographic question of the survey, participants were asked the name of the school in which they were working. Subsequently, educators were asked to select the answer that best represented their position, presented in Table 1. Finally, participants indicated the number of years they had been teaching in immersion, displayed in Table 2. Educators' perspectives are presented here in the following four categories: first, the importance of learning English and French in Saskatchewan; second, the language learning of allophone students; third, gatekeeping practices in immersion; and fourth, the overall suitability of French immersion for allophone learners. 
Table 1

Survey Responses to the Question: "Which of the following answers best describes your current position?"

\begin{tabular}{lll}
\hline Answer & Count & $\%$ \\
\hline $\begin{array}{l}\text { Primary Years Teacher } \\
\text { (Kindergarten - Grade 2) }\end{array}$ & 17 & 30.36 \\
$\begin{array}{l}\text { Middle Years Teacher } \\
\text { (Grade 3 - 5) }\end{array}$ & 14 & 25.00 \\
$\begin{array}{l}\text { Senior Years Teacher } \\
\text { (Grade 6 - 8) }\end{array}$ & 10 & 17.86 \\
$\begin{array}{l}\text { Administrator } \\
\text { Resource Teacher }\end{array}$ & 6 & 10.71 \\
General/Specialist Teacher & 3 & 5.36 \\
Teacher Librarian & 1 & 5.36 \\
\hline
\end{tabular}

Table 2

Survey Responses to the Question: "Including the 2016-2017 school year, how many years have you been teaching in a French immersion program?"

\begin{tabular}{cll}
\hline Answer (in years) & Number of teachers & $\%$ \\
\hline $1-5$ & 30 & 53.57 \\
$6-10$ & 12 & 21.43 \\
$11-15$ & 3 & 5.36 \\
$16-20$ & 5 & 8.93 \\
$21-25$ & 1 & 1.79 \\
$26-30$ & 3 & 5.36 \\
\hline
\end{tabular}

\section{Questions for Educators}

The importance of learning English and French in Saskatchewan. The first two questions of the online survey for educators measured the extent to which French immersion teachers and principals believed that it was important for allophone students in Saskatchewan to learn English (Figure 1) and French (Figure 2). Both items yielded positive results, albeit more resoundingly in favour of the importance of English. The following interview excerpt delineates one educator's perspective on the two languages:

I don't know, like, people that are from this country-it's not that they forget about the French, but they just-I don't know. It's almost like people coming from these other countries value it way more, coming in. They go, "Oh, it's French and 
English! You need to do both! This is important!"

- Britney, Grade 2 Teacher

Indeed, many teachers and principals expressed that allophone families were highly motivated to acquire both English and French, often more so than their Anglophone counterparts. In summary, the majority of educators believed that it was beneficial for allophone students to learn both languages. However, most participants stated that in Saskatchewan it is a higher priority for such students to learn English.

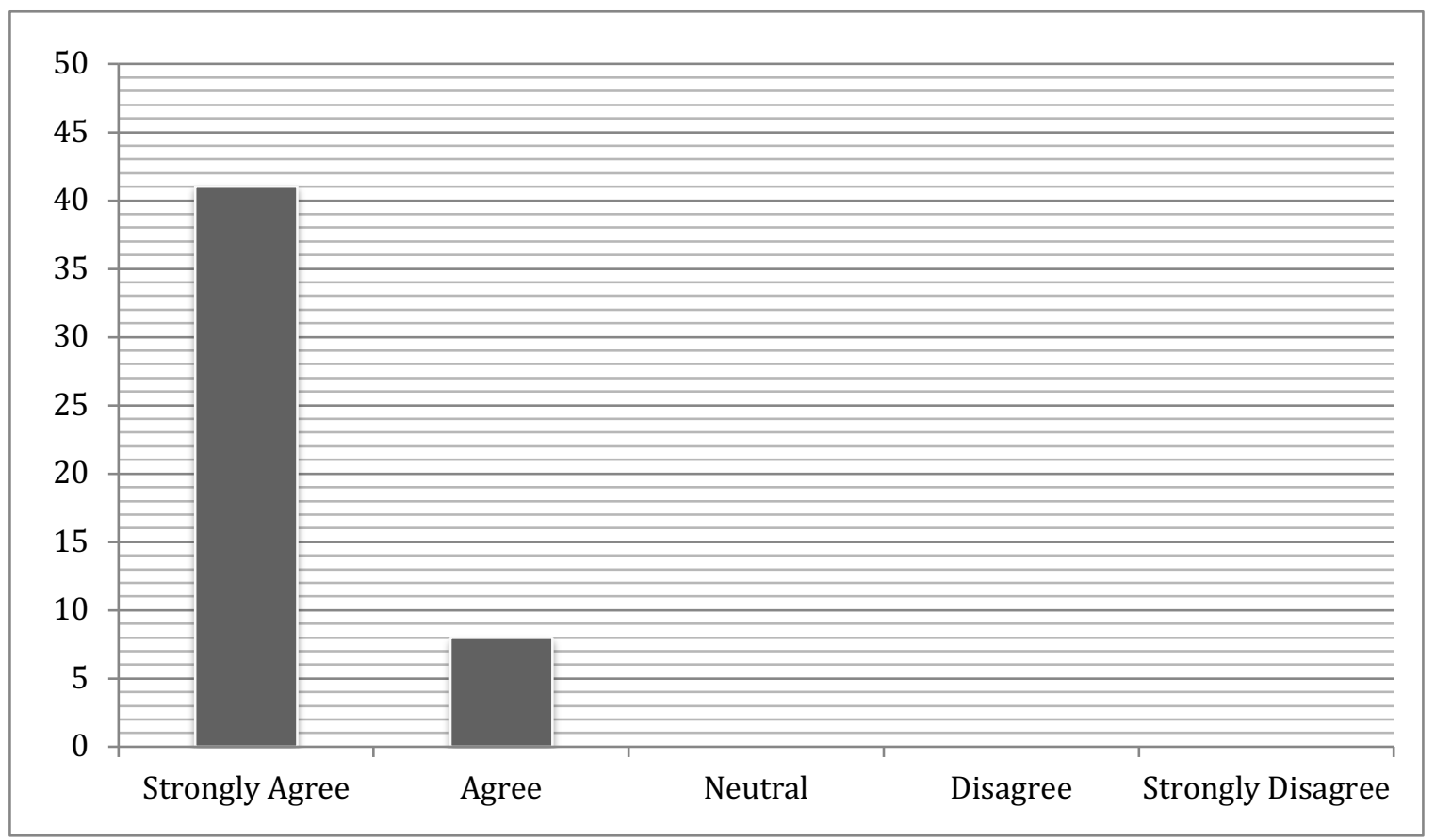

Figure 1. Survey responses to the statement: "I believe that it is important for allophone students in Saskatchewan to learn English.” 




Figure 2. Survey responses to the statement: "I believe that it is important for allophone students in Saskatchewan to learn French.”

Allophone language learning. A subsequent survey question assessed the extent to which participants believed that allophone students were learning French effectively (Figure 3). Additionally, educators were asked whether they believed that allophone students were acquiring English effectively in French immersion, which also generated positive findings (Figure 4). However, although several educators affirmed that allophone students were learning English at school and beyond the classroom, some expressed concern with the lack of formal English instruction and EAL support available for allophone learners in French immersion programs, as per the following excerpts:

Support in EAL would be huge for these families. And all it really does is become a disincentive for them to go into French immersion. When a new family, when Syrian families are arriving, and they say, "We'd like to go into French immersion," and I say, "You're more than welcome, but just so you know, there's no English language support until the end of Grade 2," that becomes a roadblock to them, you know?

\section{- Darius, Principal}

Indeed, many educators expressed that allophone students are generally learning English effectively in French immersion, but some argued that more formal instruction is needed, both in terms of regular classroom instruction and intensive EAL support. Some teachers argued in their interviews that a certain degree of English proficiency was required for success in French immersion: 
I've heard some teachers in the staff room here saying, "How am I supposed to teach them French when they can't speak English?"

\section{- Kevin, Resource Teacher}

In summary, although several educators espoused the view that allophone students were developing strong English language abilities, others suggested that the lack of English proficiency amongst some learners was an obstacle for success in French immersion.

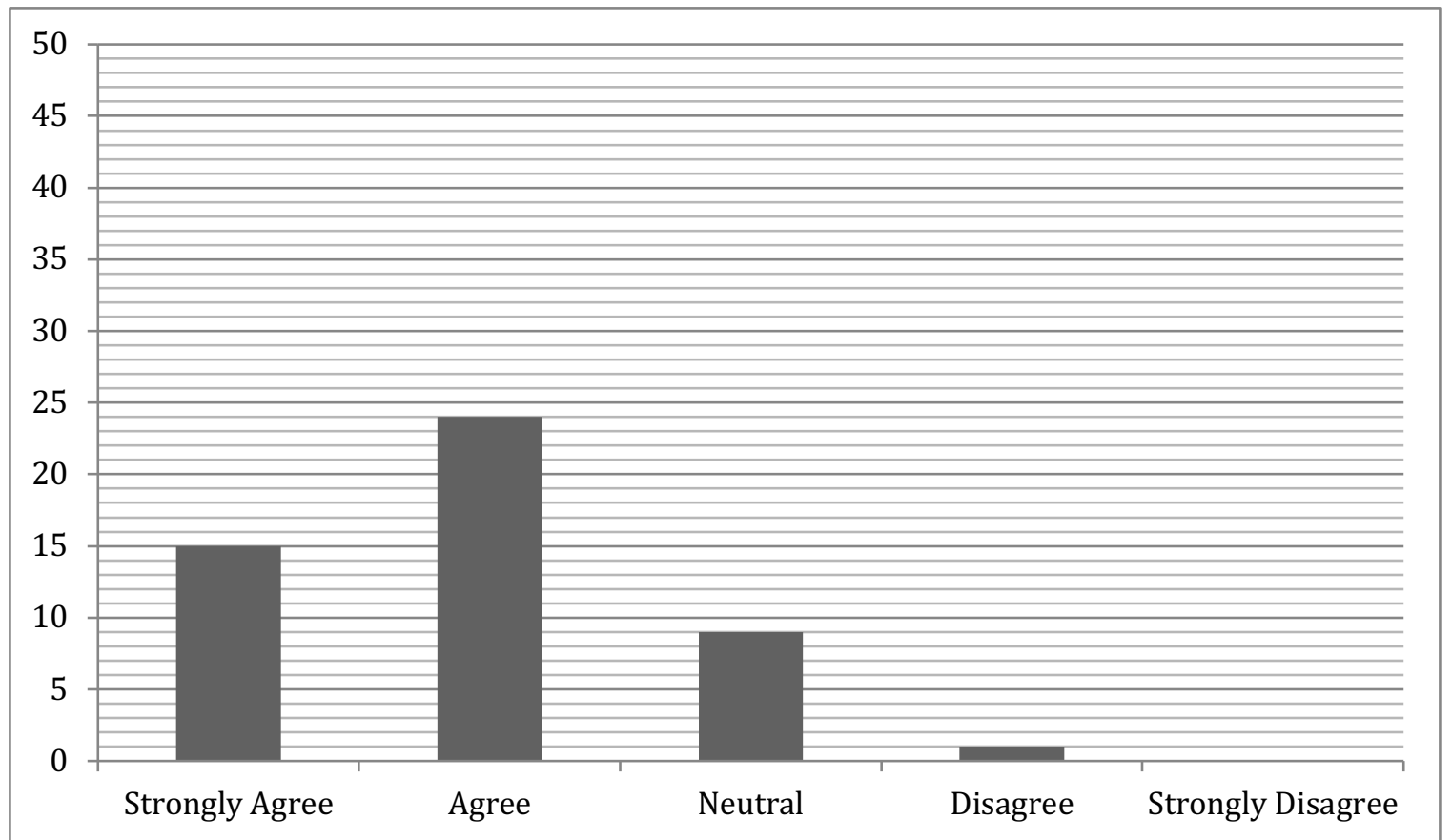

Figure 3. Survey responses to the statement: "I believe that allophone students learn French effectively in French immersion." 


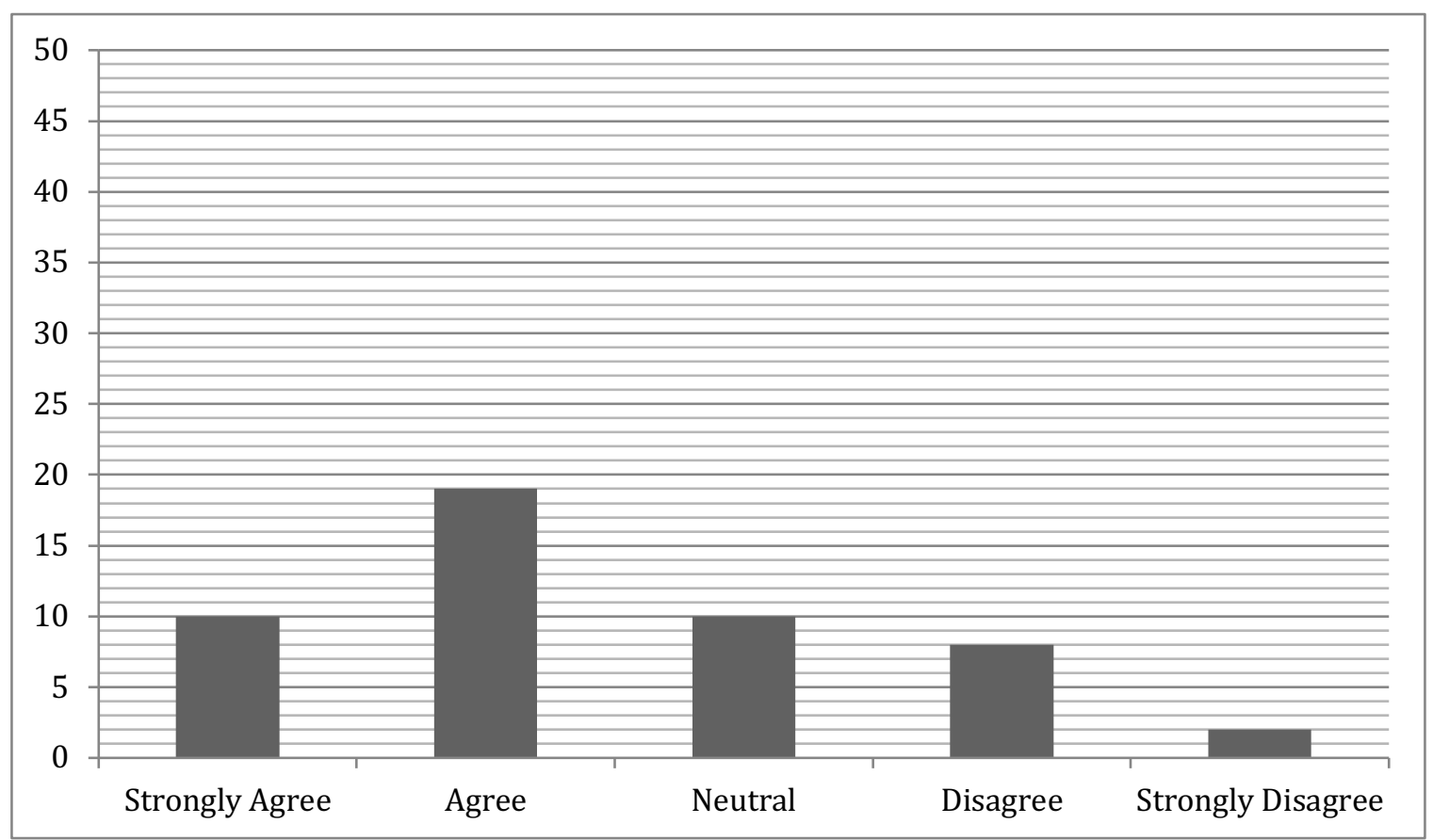

Figure 4. Survey responses to the statement: "I believe that allophone students learn English effectively in French immersion."

Educators were asked to indicate whether they believed that allophone students had disadvantages learning French compared to their Anglophone classmates (Figure 5). Some participants argued that Anglophone parents were better able to support their children's French learning than allophone parents:

I would say that there would be some difficulty for families to support them in French and in English, because most of our Canadian families have a little bit, Sesame Street French, at the very least, you know? And I think that they can support a little bit differently. Even if they don't feel bilingual or fluent, they still have knowledge of the French language, whereas some of our allophone families may have none.

- Yolanda, Principal

Thus, there is some disagreement amongst educators as to whether allophone families have disadvantages in French immersion compared to their Anglophone counterparts.

Conversely, another survey question measured participants' perspectives surrounding advantages for allophone learners (Figure 6). Many educators noted distinct advantages, such as cross-linguistic connections and less dependency on English:

Well, two of my students were from Romania last year, and so they could relate to certain words I was writing on the board. They would say, "Oh! I know that word!" just because they knew Romanian, right?

- Alfonso, Grade 4 Teacher 
I think, too, they know that most of us teachers are also English speakers, and so they default to that quickly, whereas I do not speak Urdu. I do not speak multiple languages other than French or English, and so to default to that doesn't really help us converse or understand each other better. And so I just find that they try harder in French, because it's the one thing that we might have in common.

- Jada, Vice Principal

In summary, there is significant divergence with respect to participants' perspectives regarding advantages and disadvantages for allophone students in French immersion.

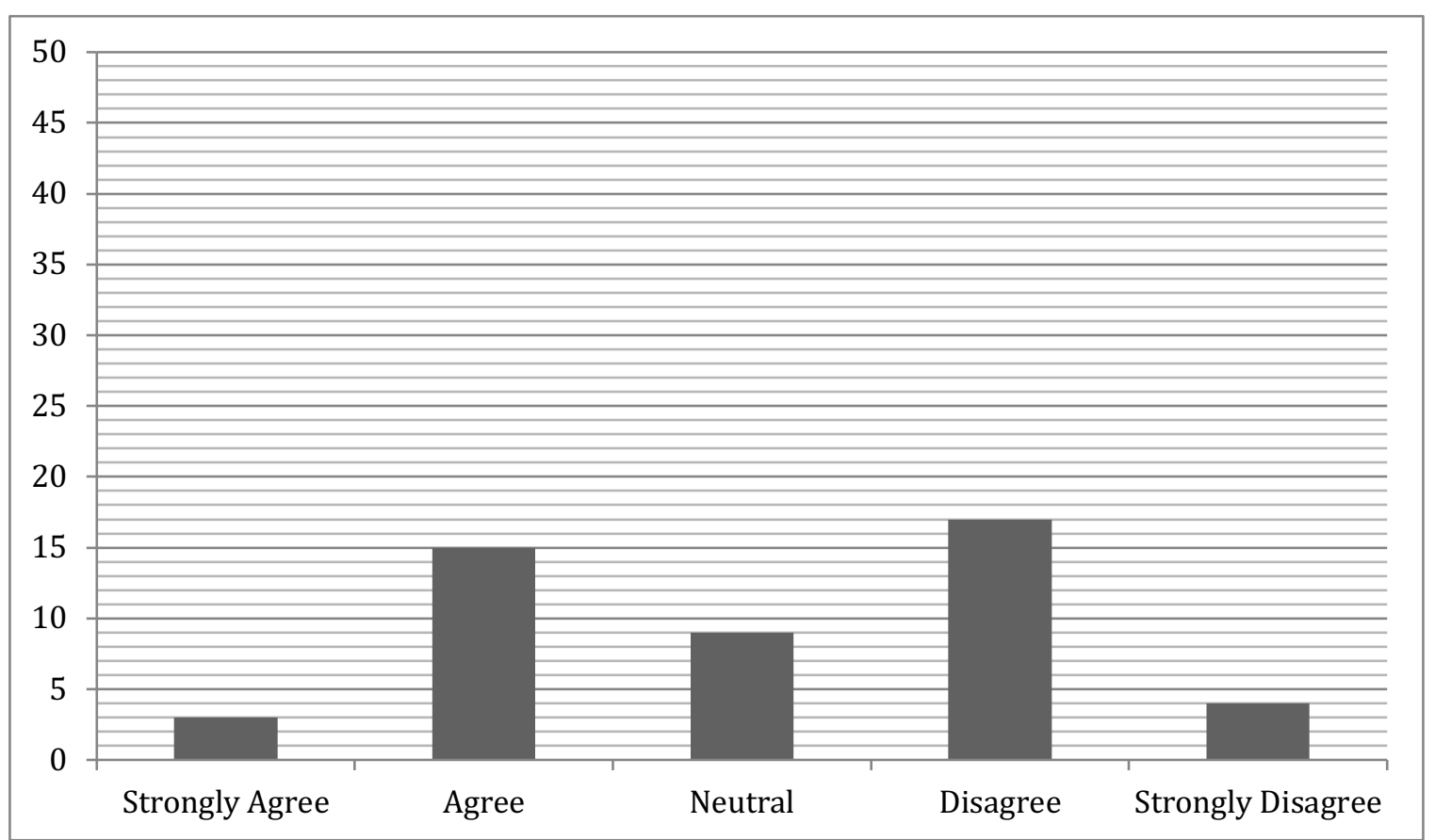

Figure 5. Survey responses to the statement: "I believe that allophone students have disadvantages learning French compared to their Anglophone peers." 


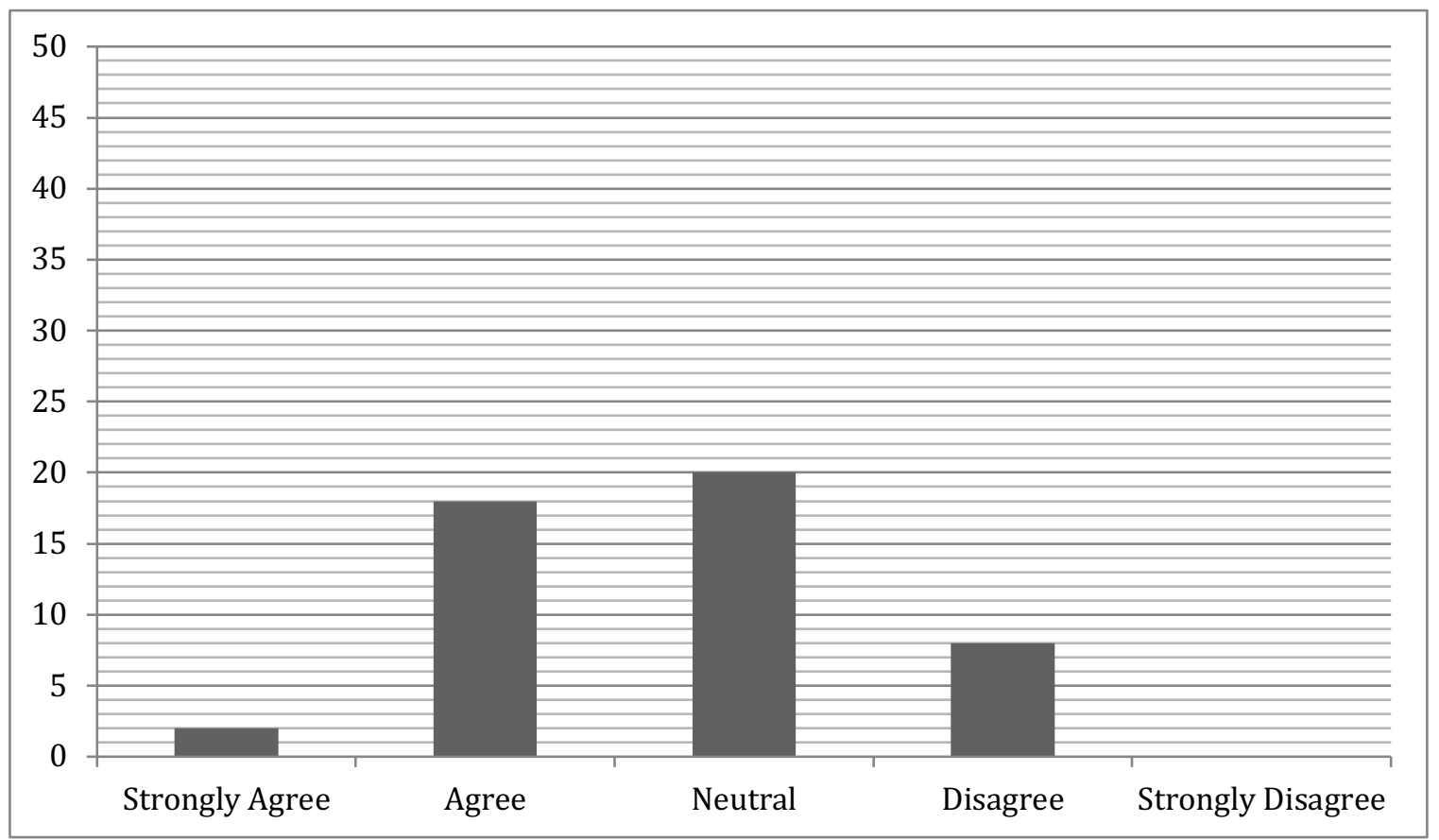

Figure 6. Survey responses to the statement: "I believe that allophone students have advantages learning French compared to their Anglophone peers."

Gatekeeping. This section provides the results of this study concerning the gatekeeping function of teachers and principals - that is, the role educators play in the inclusion or exclusion of allophone students in French immersion. To this end, one survey item suggested that allophone learners should be included in French immersion, which generated resoundingly positive results (Figure 7).

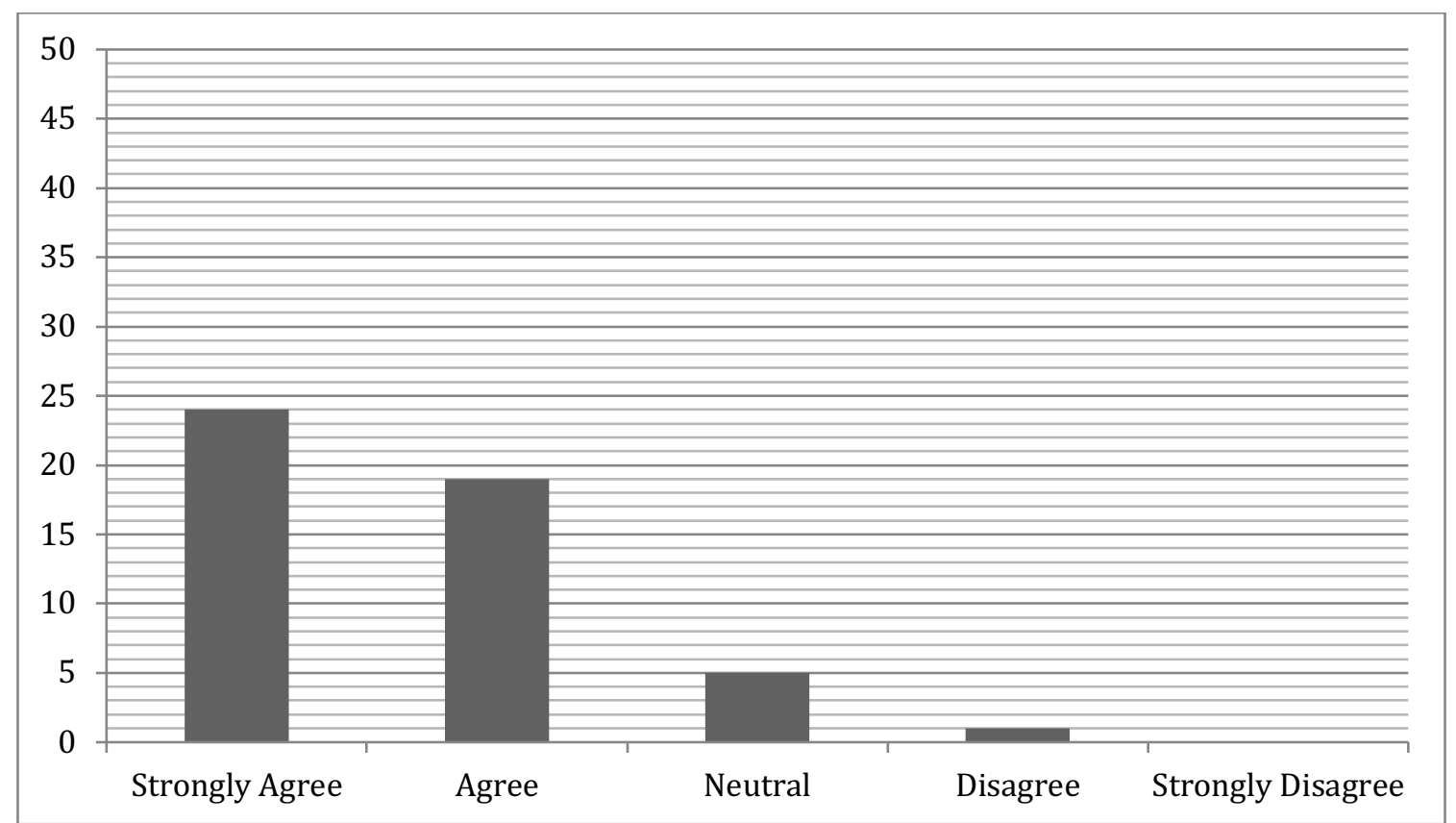

Figure 7. Survey responses to the statement: "I believe that allophone students should be included in French immersion." 
The inclusion of allophones was also discussed in interviews, which further illustrated the diverse positions displayed in the survey results. For instance, one principal indicated that his inclusion of allophone learners was met with opposition from co-workers:

We have two examples in late French immersion this year, one where the student's coming in and speaking no English at home, and lots of people were saying, "Oh, she should just go into English. She shouldn't go into French.” And I wasn't discouraging to the parent, but I pointed out that it could be an added challenge. But Mom just kept saying that she had always had this dream of learning French, and this was her chance to learn French, and she wanted to learn French, and so we put her in the program and away she went. She's doing fabulously.

- Darius, Principal

In this vein, a teacher from the same school expressed her concerns for allophone students in French immersion, referring to the integration of Syrian refugee children:

I think a lot of the ones we've been getting, like, we've gotten lots of families from Syria at this school. I think they're just struggling to, you know, have proper clothing and lunches. I just think they think, you know, let's . . . I mean, it's an old fact, I mean, obviously if they're teaching in French, it's just another stress at home, and I think we should just look at it as "let's learn English first."

- Britney, Grade 2 Teacher

Evidently, educators differ as to whether allophone learners should be included in French immersion. Although the survey item yielded positive results, interview data suggest significant divergence in views on this issue.

Additional survey items examined the extent to which educators believed that teachers and principals should be able to decide whether to include or exclude such learners from the program (Figure 8) and whether allophone parents should be able to select the instructional program for their children (Figure 9). The vast majority of educators affirmed that allophone parents have the right to choose the program of study for their children, but some argued that teachers and principals should have the authority to remove such students from immersion, as seen in the following excerpt:

I don't know how you could introduce any screening to see if the child is suitable, but I feel, right now, there's a lot of kids — and I'm not just talking about my classroom — but French immersion probably isn't the best place for them. - Andrea, Grade 1 Teacher

Indeed, the gatekeeping function of educators was a subject of controversy amongst participants, and although most educators indicated that allophones should have access to immersion, some argued that teachers should have the right to exclude certain learners. 


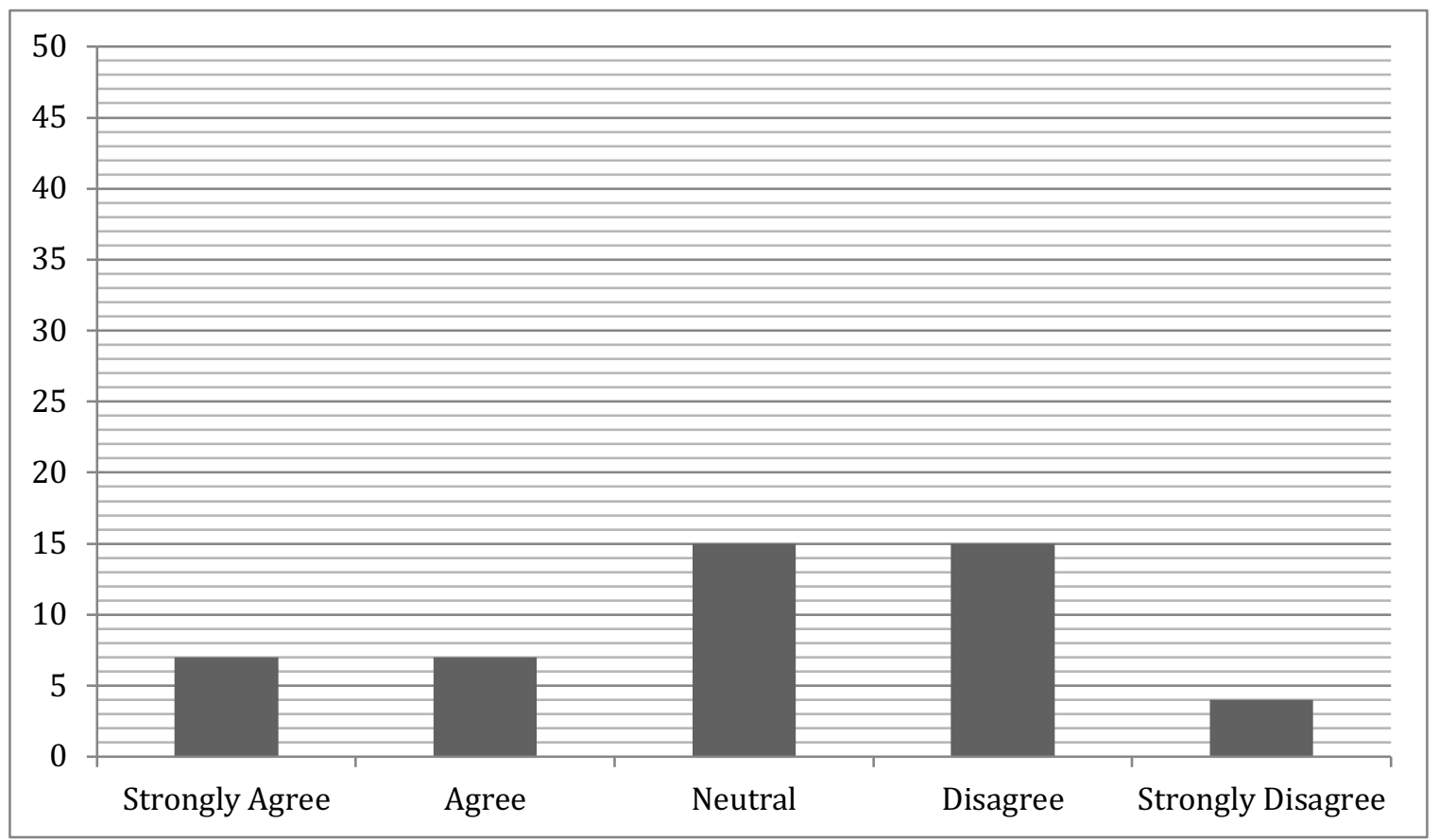

Figure 8. Survey responses to the statement: "I believe that school administrators and teachers should be able to decide whether or not to include allophone students in French immersion."

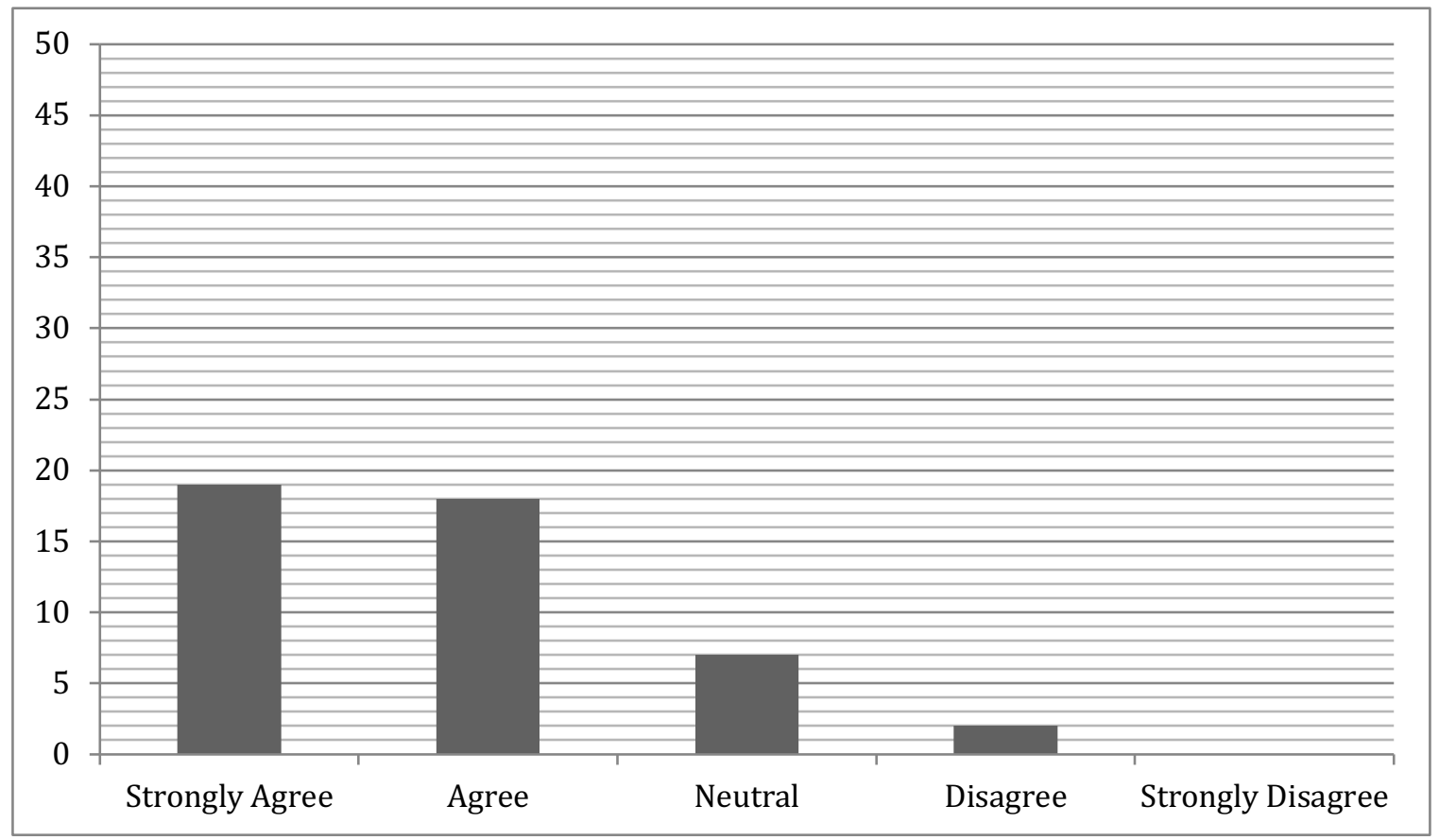

Figure 9. Survey responses to the statement: "I believe that allophone parents should be able to select the program of study for their children."

The suitability of French immersion for allophone students. The survey item measuring the suitability of French immersion for allophones generated positive results 
(Figure 10). Several administrators stated that the collective perception of French immersion being suitable for allophone students has shifted in recent years:

I'm seeing it being less and less of an elitist program. I've lived that, you know, that whole attitude for the last 15-20 years . . . I think that as long as we're providing the proper supports for these children like we would for any program, then there's no reason why we can't have students with special needs or allophones coming in and learning another, like, learning French as opposed to just English.

- Josephine, Vice Principal

And I would say, in the last five years, there's a big shift in French immersion being for all and accessible to all, whereas when I was a French immersion student, it was very much an elitist program. And if you did not fit into that program and you were not successful without any accommodations or adaptations, you simply were removed from the program.

- Jada, Vice Principal

However, some teachers argued that immersion was inappropriate for certain students, and others opined that late French immersion was more suitable than the early option:

But then the other thing is that they, oftentimes in many divisions [i.e., in many school boards], push French immersion as being for everybody. "French immersion is for everyone! French immersion is for everyone!" I just don't think that's true! - Billy, Grade 7 Late French Immersion Teacher

I think the ideal would be core French, and then do late French immersion. I think that's a perfect transition. Like, get your English, which is, like, what you need to survive in Saskatchewan, and then you can still get French immersion and catch up. - Jennifer, Grade 2 Teacher

In summary, although the survey results demonstrate generally positive findings amongst educators regarding the suitability of French immersion for allophone students, the interview data reflect more nuanced beliefs about the suitability of different programs. 


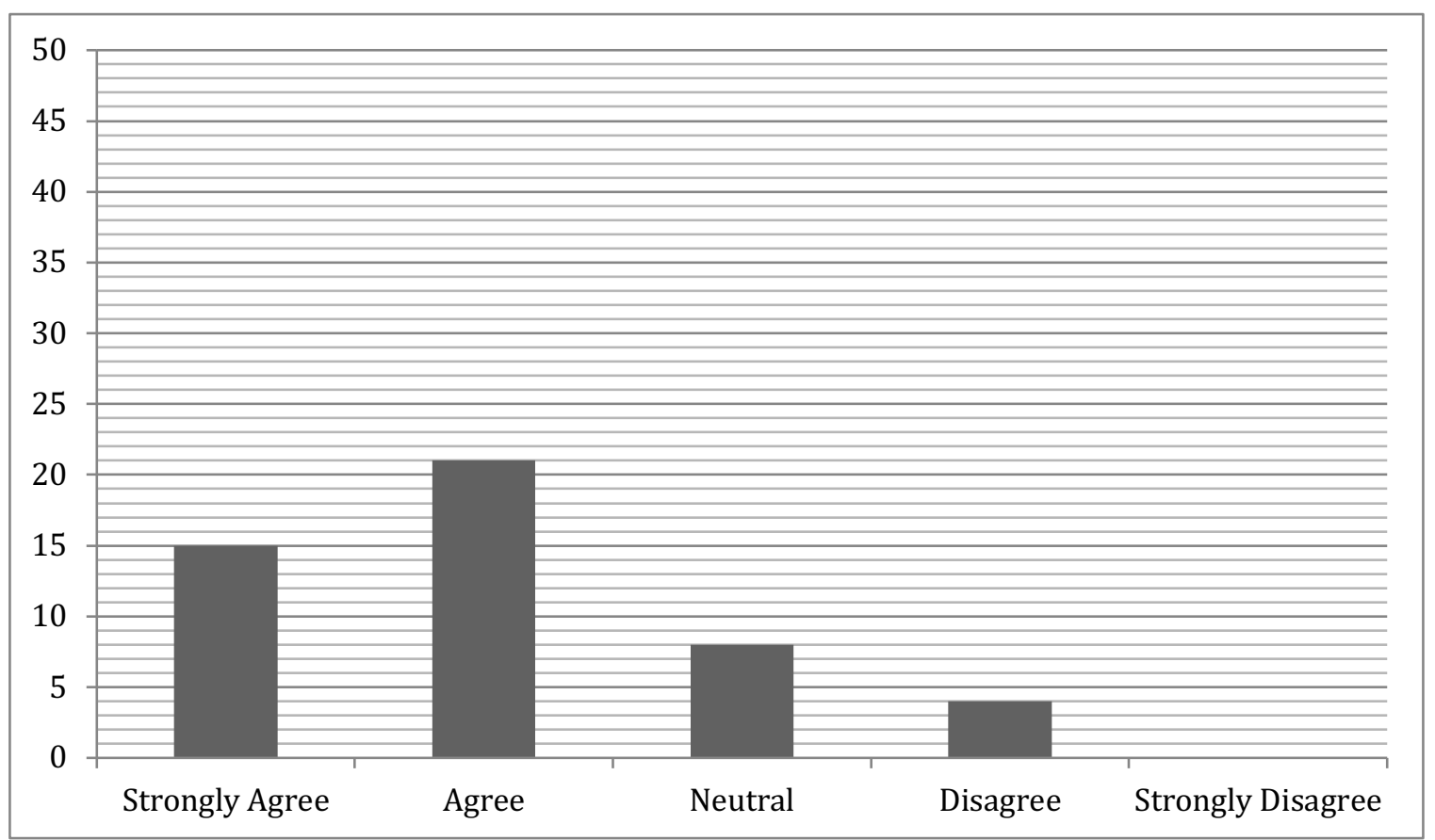

Figure 10. Survey responses to the statement: "I believe that French immersion is a suitable program for allophone students."

Subsequently, one questionnaire item assessed the extent to which teachers and principals would recommend French immersion for a student with limited English proficiency. This item generated diverse responses (Figure 11). In contrast, another survey question measured whether educators would discourage allophone families from enrolling their children in French immersion (Figure 12). Although most participants refuted the questionnaire item, interview data reflect a degree of apprehension for some:

I think teachers should be able to be honest with parents about where their kids are at. I feel like sometimes I'm not able to be honest with parents ...

- Jennifer, Grade 2 Teacher

In summary, most educators expressed that they would not discourage allophone families from enrolling in French immersion, but some teachers felt prohibited from dissuading such families in light of expectations from the school board. 


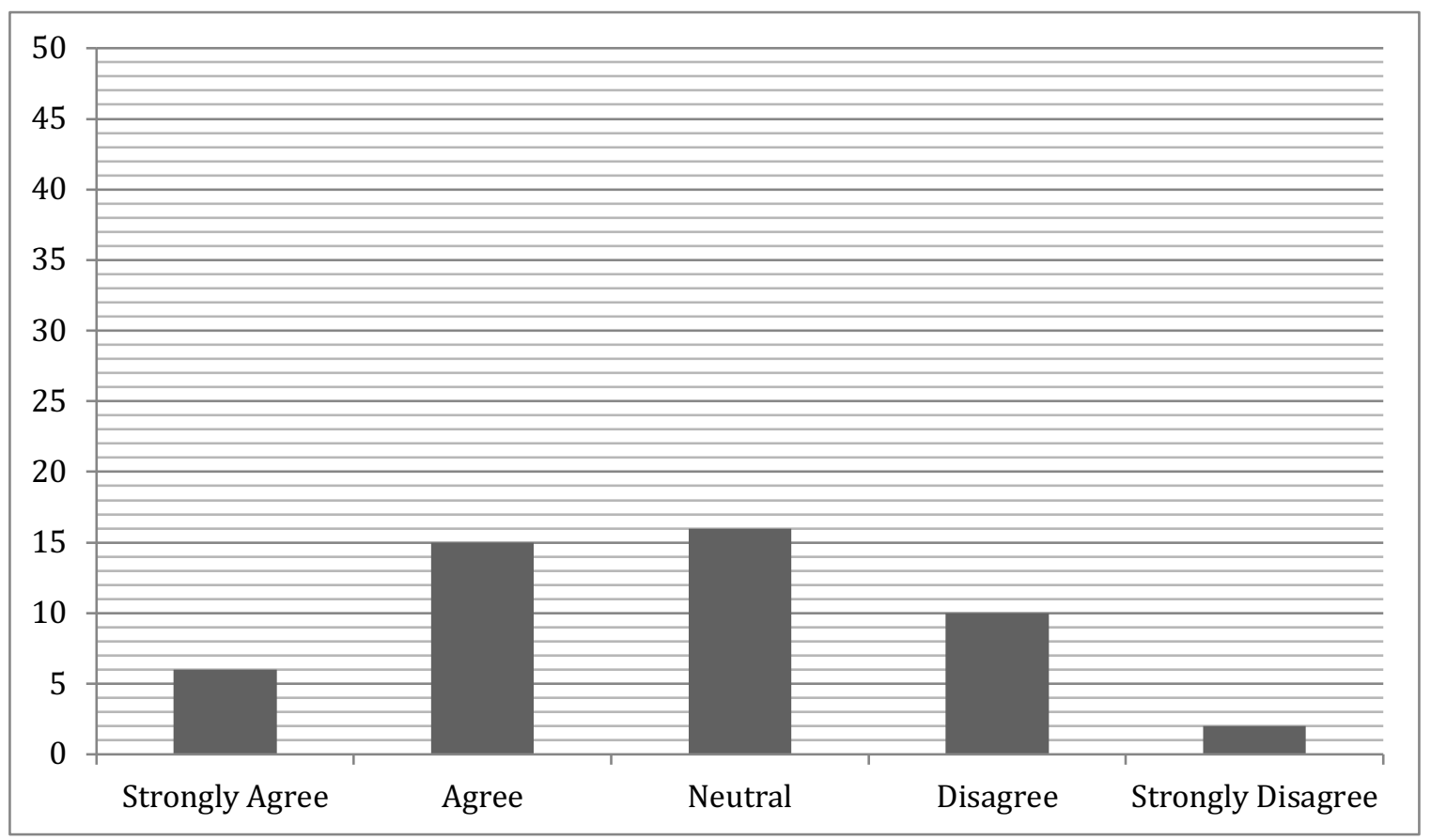

Figure 11. Survey responses to the statement: "I would recommend French immersion for a student with limited English proficiency."

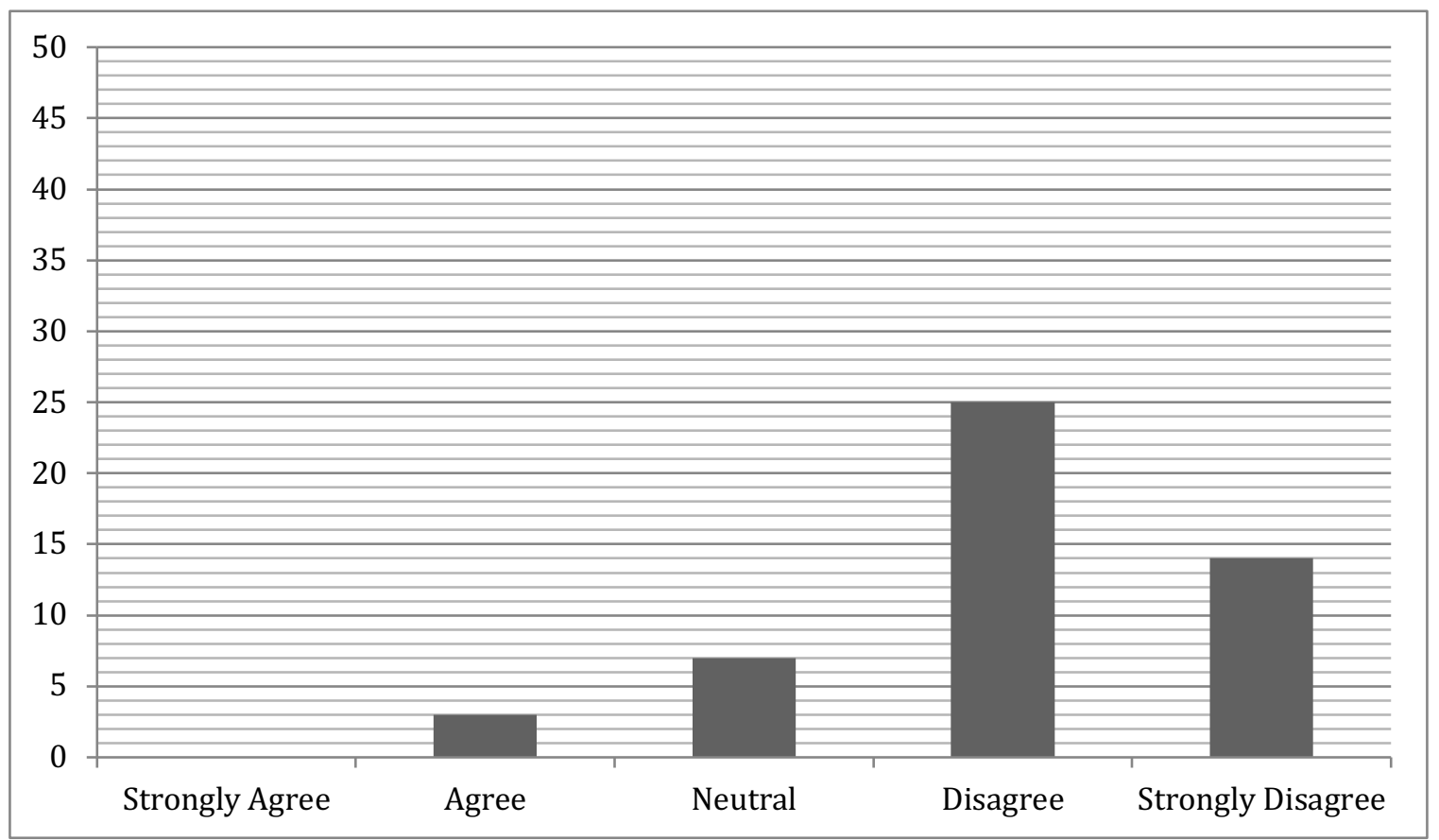

Figure 12. Survey responses to the statement: "I would discourage allophone families from enrolling their children in French immersion." 


\section{Results: Parents' Perspectives}

\section{Demographic Information}

In the first three demographic questions, parents were asked to indicate their children's schools, the number of children in their families enrolled in immersion, and the amount of time that they had lived in Canada. Parents were also asked to specify their children's grade levels (Table 3) and the number of years they had been enrolled in immersion (Table 4). The grade levels of participants' children ranged from Kindergarten to Grade 7, and the number of years of study in immersion also varied considerably. Among the eight parents who stated that their children were in their first year of immersion, five of the students were in Kindergarten, one was in Grade 1, and two were in Grade 6, most likely in their first year of the late French immersion program.

Table 3

Survey Responses to the Question: "What is your child's current grade level?"

\begin{tabular}{lll}
\hline Answer & Count & $\%$ \\
\hline Kindergarten & 5 & 21.74 \\
Grade 1 & 2 & 8.70 \\
Grade 2 & 0 & 0.00 \\
Grade 3 & 4 & 17.39 \\
Grade 4 & 1 & 4.35 \\
Grade 5 & 1 & 4.35 \\
Grade 6 & 4 & 17.39 \\
Grade 7 & 3 & 13.04 \\
\hline
\end{tabular}

Table 4

Survey Responses to the Question: "Including the 2016-2017 school year, how many years has your child been enrolled in a French immersion program?"

\begin{tabular}{lll}
\hline Answer & Count & $\%$ \\
\hline 1 & 8 & 34.78 \\
2 & 1 & 4.35 \\
3 & 2 & 8.70 \\
4 & 3 & 13.04 \\
5 & 0 & 0.00 \\
6 & 3 & 13.04 \\
7 & 3 & 13.04 \\
\hline
\end{tabular}


In addition to the five demographic questions examining the experiences of participants' families with French immersion and living in Canada, three items explored the language practices and linguistic repertoires of such families. To this end, the sixth item asked parents to provide the number of languages that their children speak (Table 5).

Table 5

Survey Responses to the Question: "How many languages does your child speak, including French and English?"

\begin{tabular}{lll}
\hline Answer & Count & $\%$ \\
\hline 1 & 1 & 4.35 \\
2 & 7 & 30.43 \\
3 & 10 & 43.48 \\
4 & 2 & 8.70 \\
\hline
\end{tabular}

Subsequently, parents were asked to list the languages spoken by their children. This item generated various combinations of the following 12 languages, presented here in order of the frequency with which they appeared in the answers: English (19), French (12), Chinese (8), Urdu (3), Bangla (2), Hindi (2), Spanish (2), Afrikaans (1), Arabic (1), and Filipino (1). Finally, the eighth demographic item of the survey for allophone parents sought to measure the languages that participants considered to be their children's strongest languages. The results, again in order of the frequency in which each language appeared in the responses, are as follows: English (18), Bangla (2), Chinese (3), French (2), and Spanish (1). The next sections provide the results of the parent surveys and interviews as they relate to the importance of English and French in Saskatchewan, language learning, gatekeeping, and the overall suitability of French immersion for allophone learners.

\section{Questions for Parents}

The importance of learning English and French in Saskatchewan. The first two questions of the survey sought to juxtapose the relative importance of learning English and French for allophone families in Saskatchewan. Survey results and interview data revealed that all participants viewed the English language to be critically important for their children, not only because the language is considered essential for life in Canada, but also because of its prevalence globally (Figure 13). Similarly, parents were asked the same question about learning French, which yielded slightly less pronounced results than the question about English (Figure 14). Several parents expressed that it was important for their children to learn both English and French due to the official status of these languages in Canada:

Canada has two official language. And then we thought about, maybe, we really like the idea about diversity, culturally, because we are minority, right? We like the policy maybe keep Canada as diversity as possible.

- Li, Parent

Canadian Journal of Applied Linguistics: 22, 2 (2019): 27-63 
We're a bilingual country and they should receive both.

- Duncan, Parent

Thus, the vast majority of parent participants expressed the belief that it was important for their children to learn both English and French.



Figure 13. Survey responses to the statement: "I believe that it is important for my child to learn English."

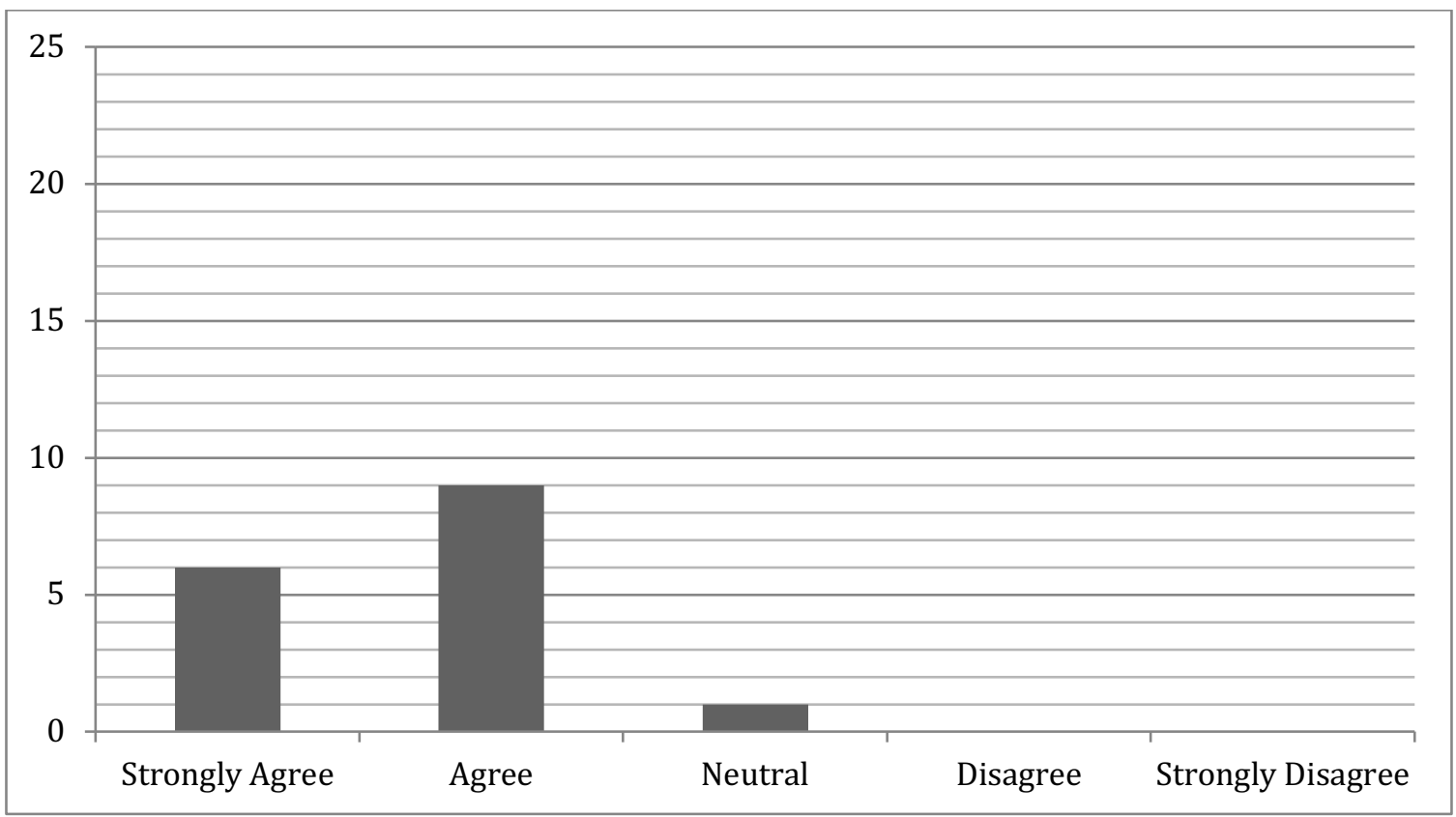

Figure 14. Survey responses to the statement: "I believe that it is important for my child to learn French." 
Allophone language learning. Here, the perspectives of allophone parents regarding the language learning of their children in French immersion will be presented. Namely, parents were asked to indicate whether they believed their children were learning English effectively in French immersion (Figure 15), and another survey item asked the same about French (Figure 16). Survey and interview participants were confident in their children's abilities to learn both languages:

I don't think it would be difficult for her. You know, it depends the mind. I think she is very good for two languages. It's not that much. And English and French, I think it will be easy.

- Badawi, Parent

In summary, most parents affirmed the abilities of their children to learn both official languages in French immersion, citing the ubiquitous presence of English throughout Saskatchewan and the strong learning of French in their children's schools.

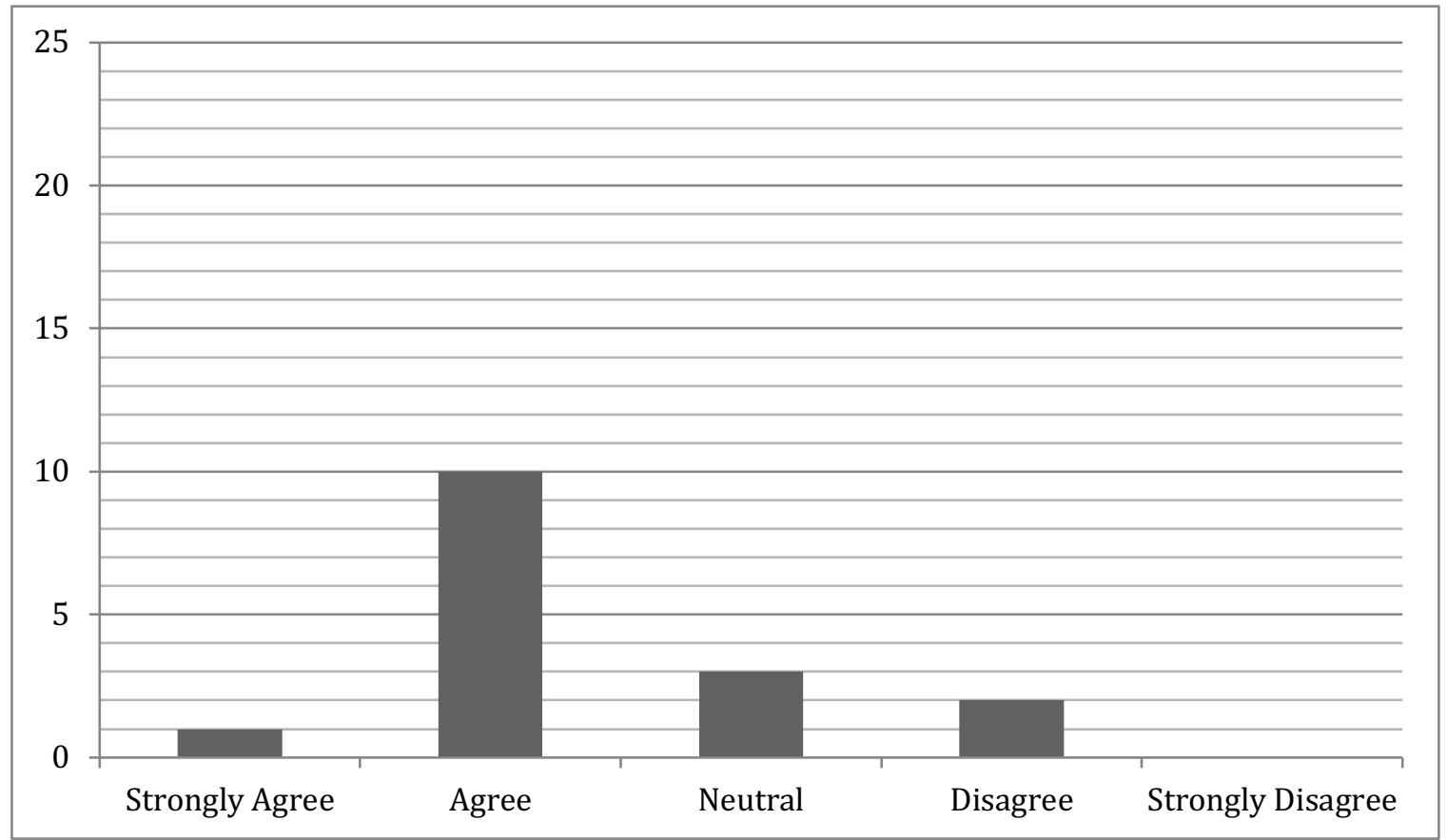

Figure 15. Survey responses to the statement: "I believe that my child is learning English effectively in French immersion." 


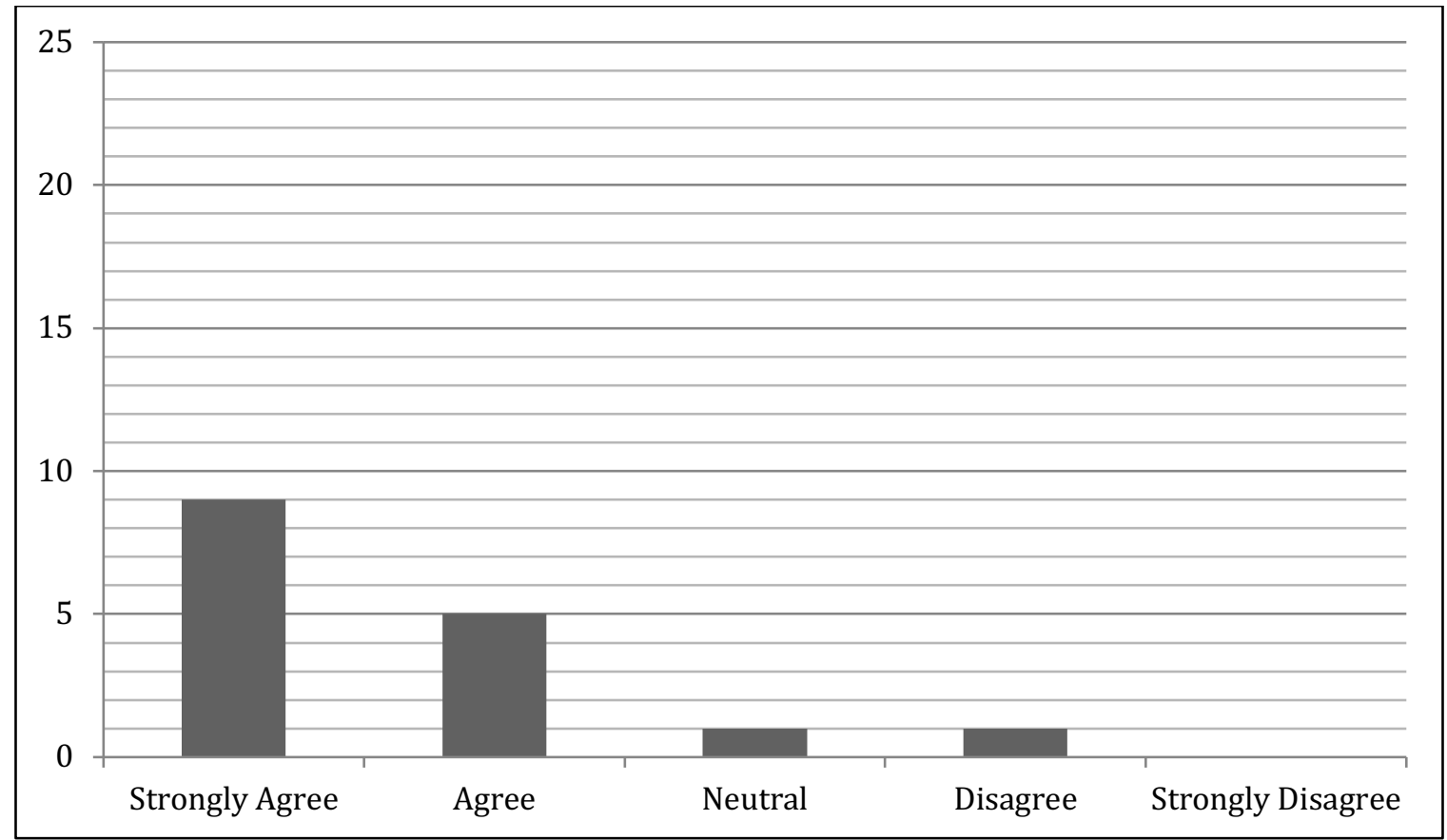

Figure 16. Survey responses to the statement: "I believe that my child is learning French effectively in French immersion."

Parents were also asked to indicate the extent to which they believed that their children had language learning advantages in French immersion compared to Anglophone students (Figure 17). The vast majority of parents agreed that their children had advantages over Anglophone learners, noting in particular prior language learning experience and cross-linguistic transfer, as seen in the following excerpt:

And especially because there are so many words borrowed from French in Serbian language - plenty of them! Camion for truck, we don't have any other words apart from camion, and he knows that, and for sofa, and other words. So we remind him we have the same word in English, like super, for example, or same word in French. - Volodymyr, Parent

The survey results demonstrate that participants by and large did not believe their children had any disadvantages in immersion relative to Anglophone students (Figure 18); all parents except one noted only advantages for their children. 


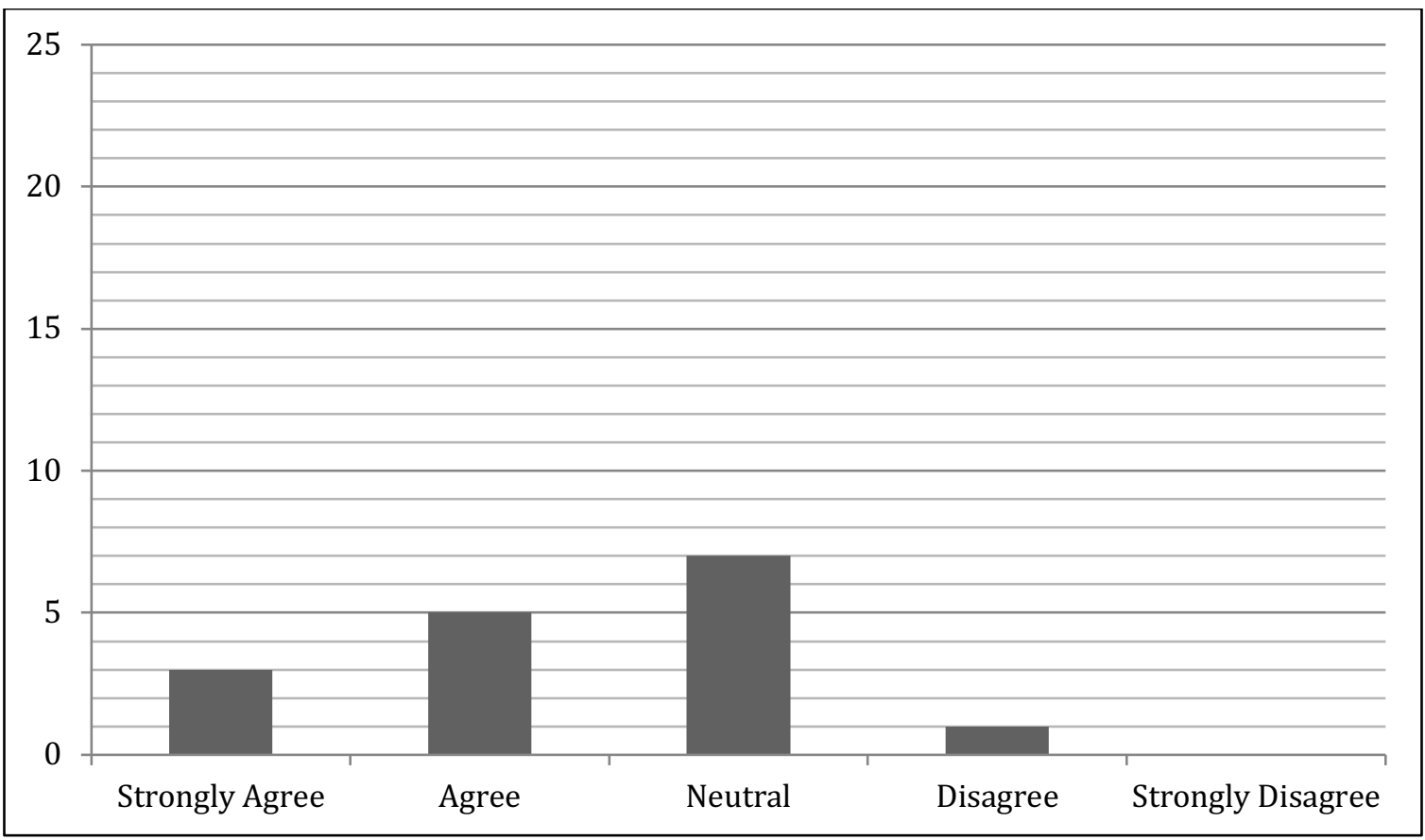

Figure 17. Survey responses to the statement: "I believe that my child has advantages in French immersion compared to students whose first language is English."

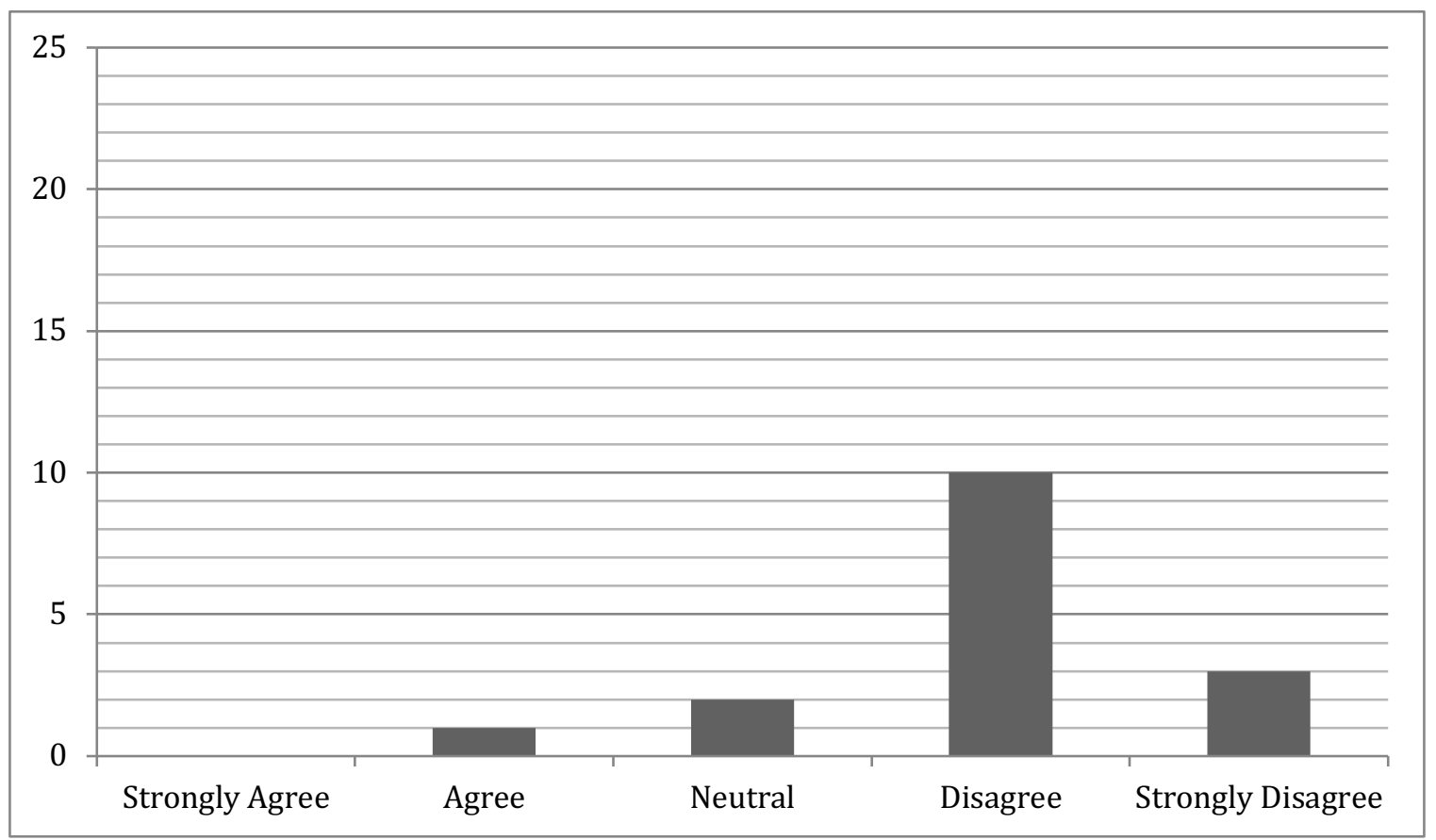

Figure 18. Survey responses to the statement: "I believe that my child has disadvantages in French immersion compared to students whose first language is English."

Gatekeeping. The findings presented here address the experiences of inclusion and exclusion of allophone families accessing French immersion. Participants were asked to indicate whether school administrators encouraged them to enrol their children in French immersion (Figure 19). This survey item generated divergent results, which were reflected 
in the interview data. For instance, one participant stated that he felt neither encouraged nor discouraged to enrol his son in French immersion:

Oh, some of them were concerned, although nobody advised us to skip that step. Some people, they, they ask, "Ok, English is not his mother tongue," but nobody was firm in the decision that he cannot go, of course. Some people were supportive. - Volodymyr, Parent

The considerable variance in the survey results, in concert with divergent interview data, denotes a range of experiences for allophone families accessing French immersion, which suggests a lack of consistent practice or policy throughout the school board.

Conversely, a subsequent question measured whether parents perceived that school administrators discouraged them from enrolling their children in immersion. The majority of participants rejected this statement (Figure 20). Several parents shared in their interviews that their children's teachers or principals had expressed concern about their families' language backgrounds potentially creating obstacles for their children in French immersion, but no participants stated that they had been discouraged outright.

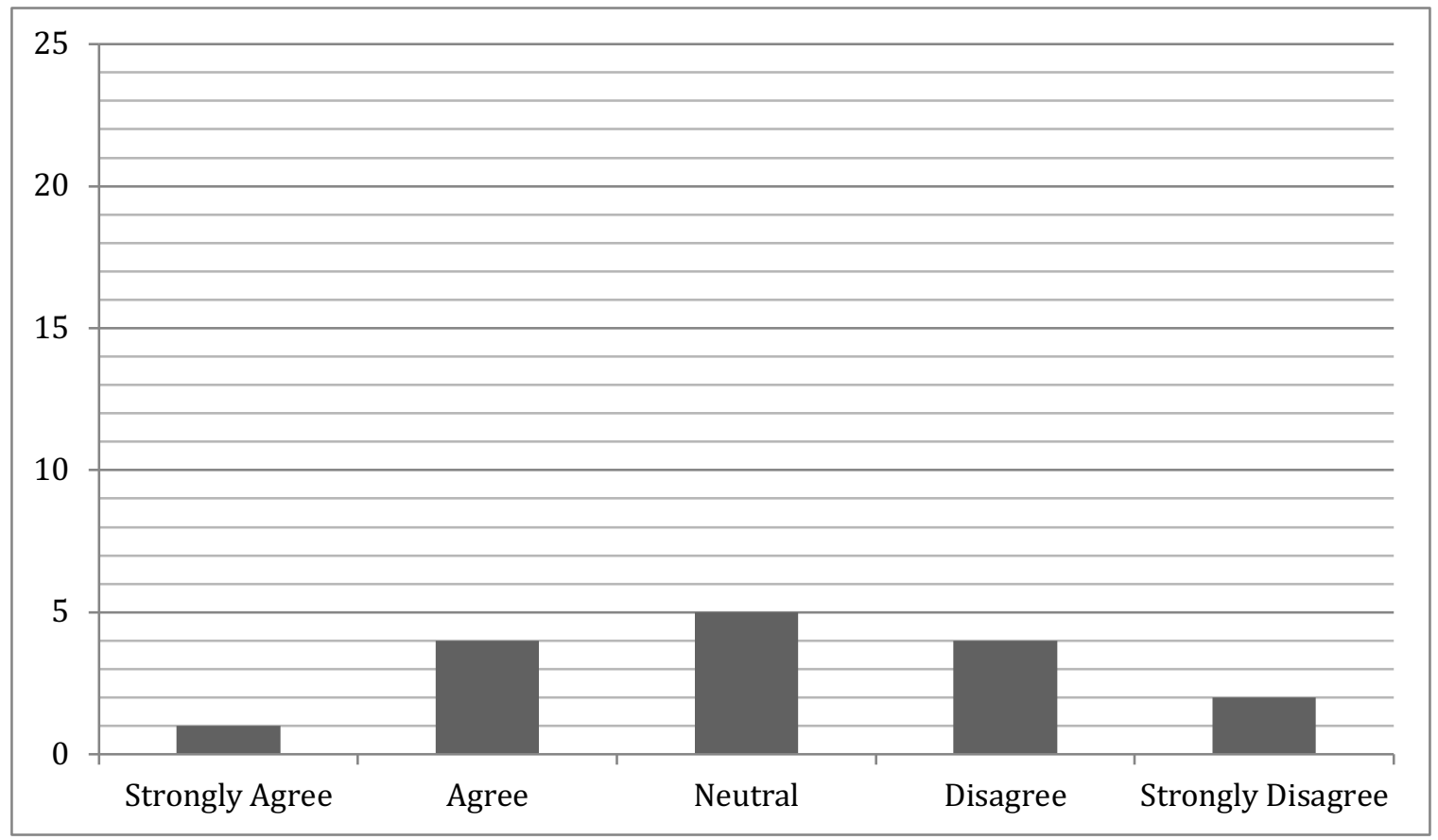

Figure 19. Survey responses to the statement: "I was encouraged by school administrators to enrol my child in French immersion." 


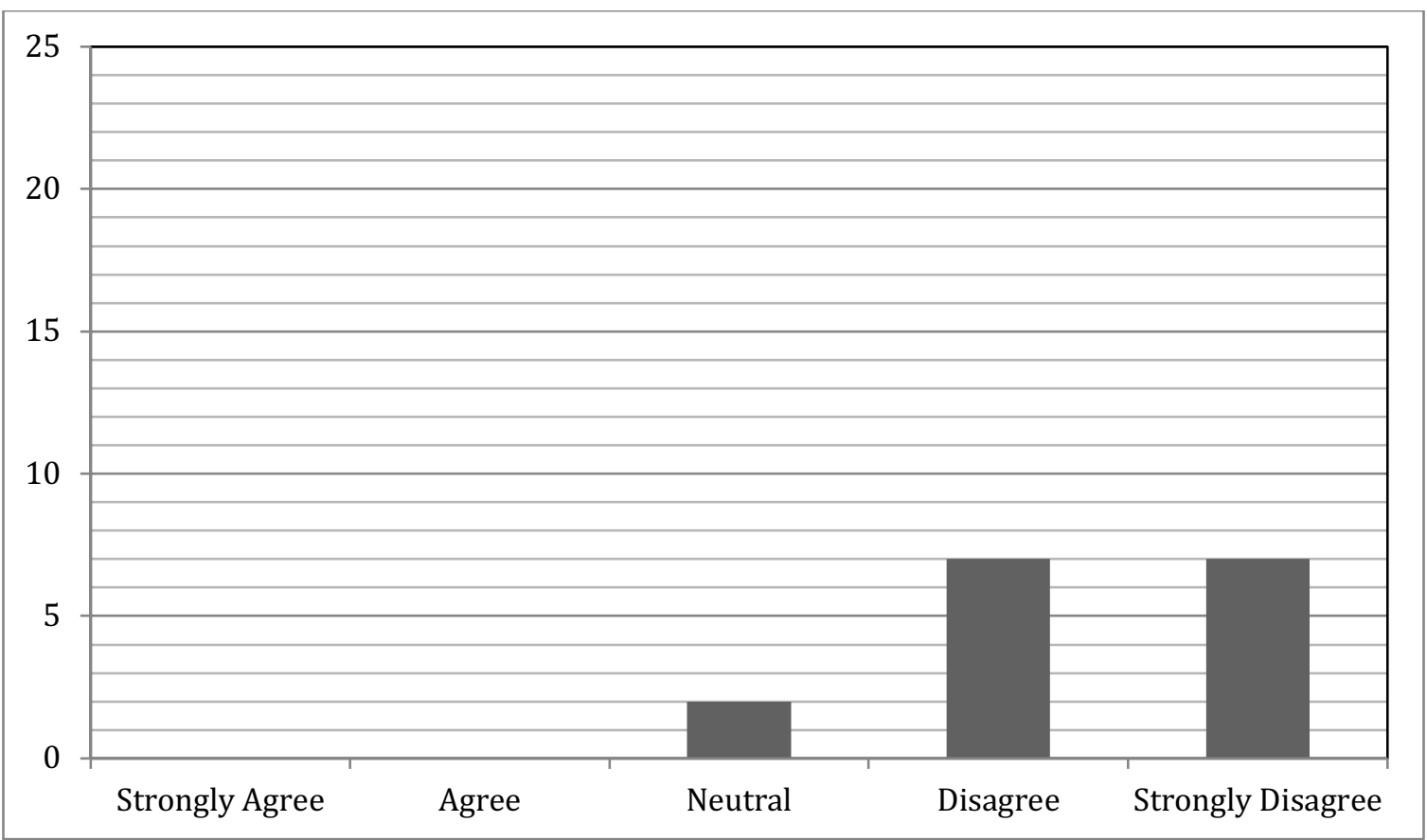

Figure 20. Survey responses to the statement: "I was discouraged by school administrators from enrolling my child in French immersion."

Whereas the above questions examined the experiences of allophone parents accessing French immersion programs, additional survey items addressed gatekeeping in more theoretical terms. For instance, parents were asked whether educators should be able to include or exclude allophone students from French immersion (Figure 21). In contrast, one survey item examined whether allophone parents believed that they should be able to select the instructional program of their children (Figure 22). Evidently, parents believed strongly that teachers and principals should not have the right to exclude allophone students from French immersion; rather, enrolment decisions should be left entirely to the families in question. 


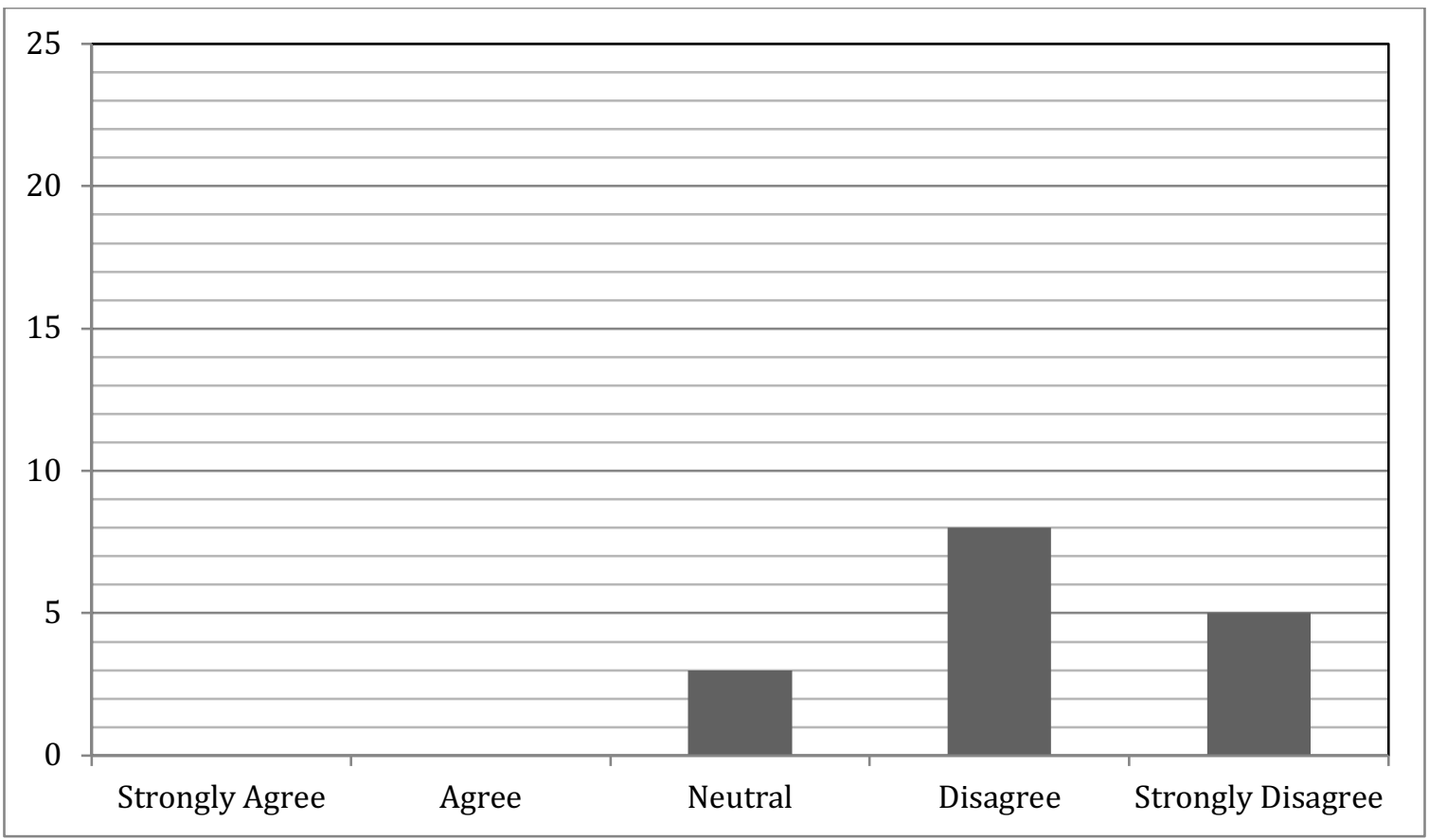

Figure 21. Survey responses to the statement: "I believe that school administrators and teachers should be able to decide whether or not to include allophone students in French immersion."

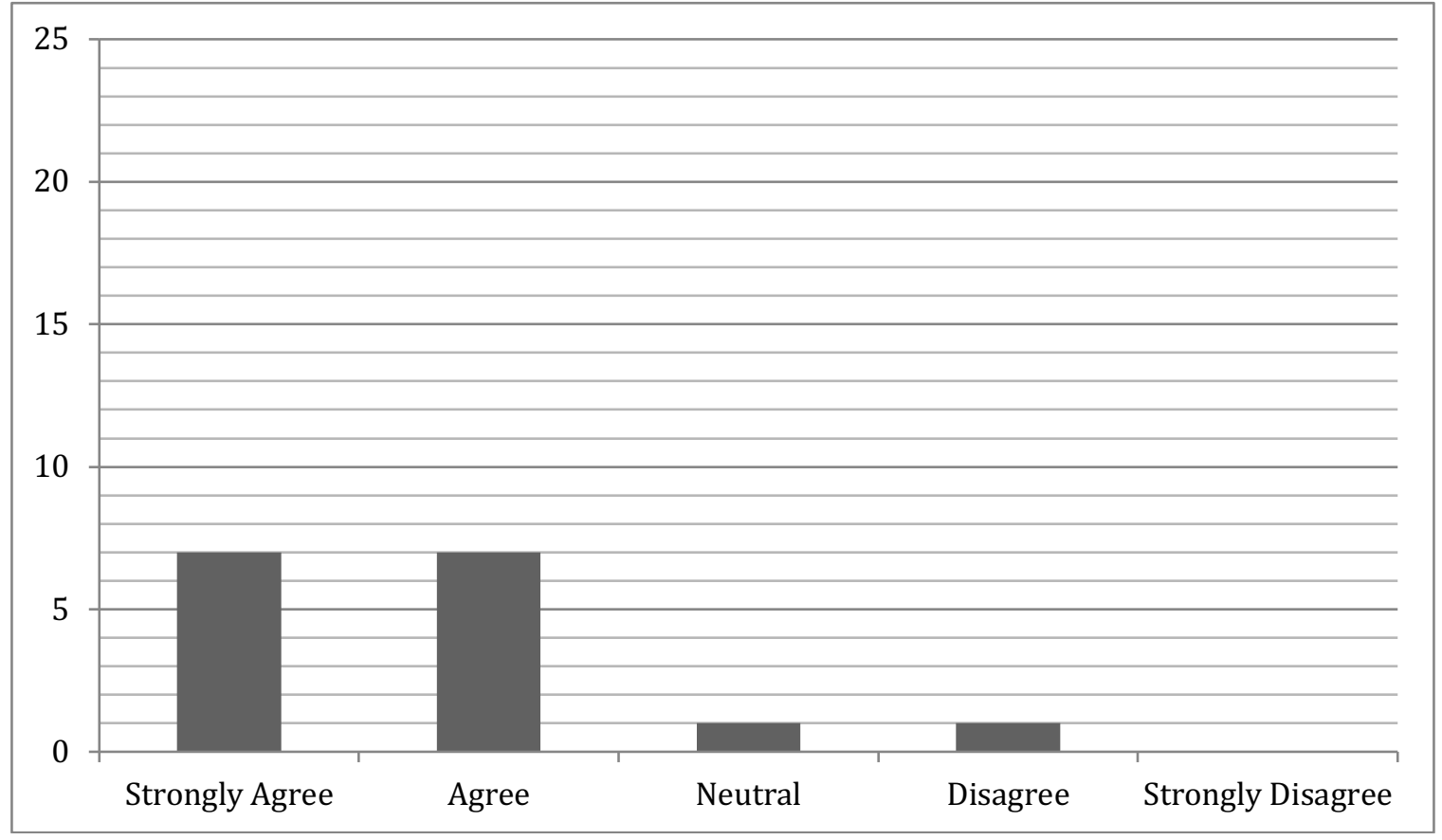

Figure 22. Survey responses to the statement: "I believe that allophone parents should be able to select the program of study for their children."

The suitability of French immersion for allophone students. In addition to examining the perceived importance of English and French in Saskatchewan, language learning for allophone students, and the experiences of allophone families accessing French 
immersion, the present study explored the beliefs of allophone parents concerning the overall suitability of such programs for their children. One survey item asked parents to indicate the extent to which they believed that French immersion was a suitable option for their children (Figure 23). The belief that French immersion was an appropriate instructional program for allophone learners was a recurring theme throughout the interviews as well. Several parents stated that French immersion was suitable because they believed the program provided enrichment for their children's learning. For example, one father explained that his son was initially enrolled in English, but the family moved him into French immersion for an additional academic challenge:

He was there for a week. But every day, he come back home saying, "I don't like the school because it's boring." Yeah, that was Grade 1. He said, "I know everything they're doing now." ... So, I was afraid that he was going to be discouraged at school, and we thought, "well, he already speaks English, and he speaks Spanish." So, it is a good opportunity for him to learn another language. - José, Parent

Similarly, one allophone interview participant offered that, although her eldest son had been invited to join an enriched version of the English program in secondary school, he decided to continue in French immersion for the added academic challenge:

Like, Muhammed, he was accepted in the advanced program, and it was his choice . . . I think he said, "all my efforts would go in vain if I just go to advanced program." He thinks that learning everything in French is in itself an advanced program. So, it's like, being bilingual is not easy; you have to switch all the time in your head, and we have other language also. So, it's like switching everywhere. So, he thought that it's more helpful to stay in French program than go into advanced.

- Kamal, Parent

Thus, most allophone parent participants who enrolled their children in French immersion continued to believe that it was a suitable program for them, citing the importance of official-language bilingualism in Canada, the appropriate challenge and enrichment that immersion provides, and the opportunities that French proficiency would present for their children in the future. The next section contains the interpretation and discussion of the findings pertaining to the perceived suitability of French immersion. 


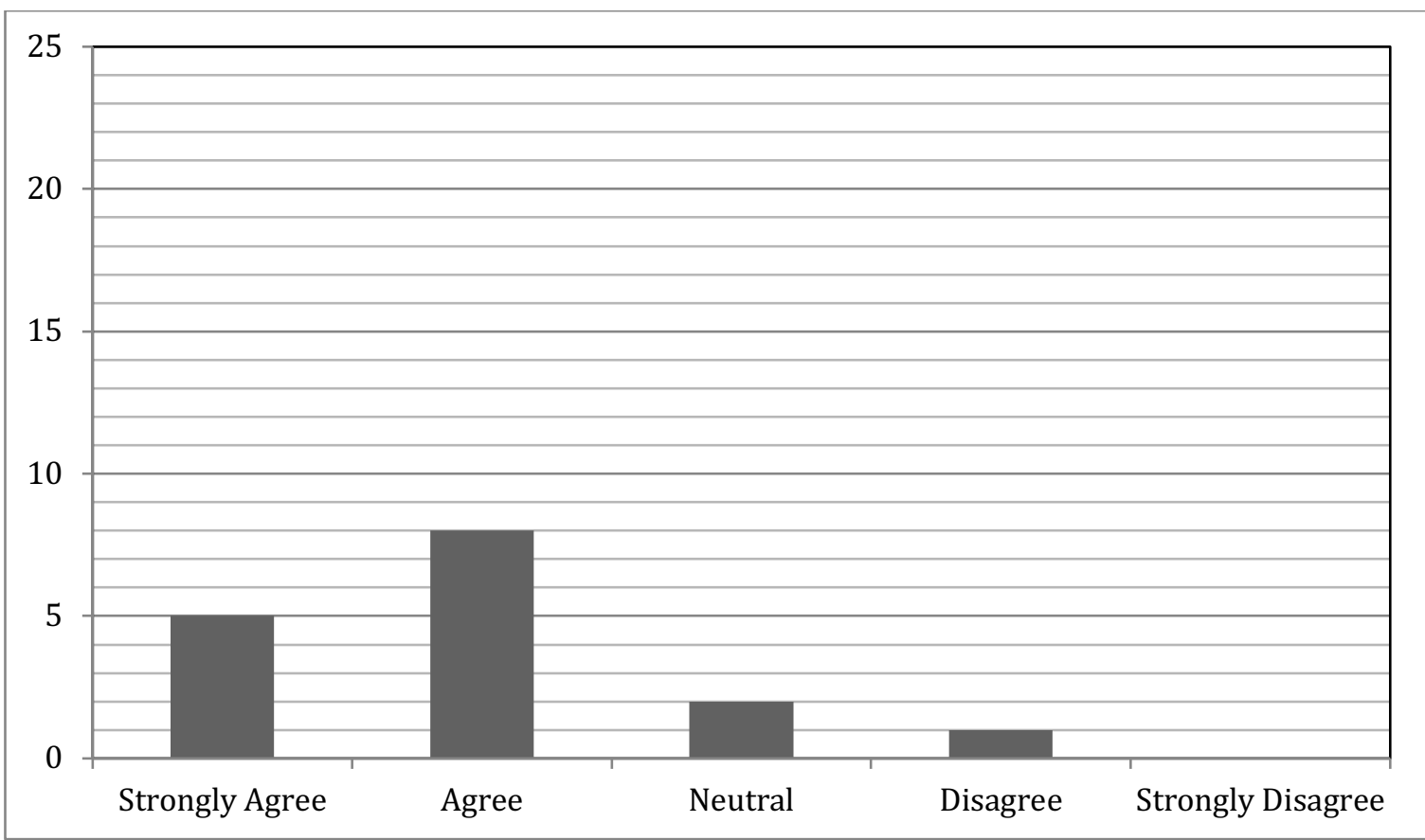

Figure 23. Survey responses to the statement: "I believe that French immersion is a suitable program for my child."

\section{Discussion}

The objective of the present study was to examine the diverse perspectives of educators and parents concerning the suitability of French immersion for allophone students in a school board in Saskatoon, Saskatchewan. Whereas the previous section of this study provided results in terms of the four central themes that emerged from the data, the discussion is organized based on the study's research questions, which examined (a) educators' and parents' perspectives on the suitability of French immersion for allophone learners and (b) parents' and educators' experiences and perspectives on gatekeeping in the program.

\section{The Suitability of French Immersion for Allophone Students}

Integral to the perceived suitability of French immersion for allophone learners is the extent to which stakeholders believe that it is important for such students to learn English and French. Virtually all educators and parents considered English the most important language in everyday life in Saskatchewan and therefore the most critical for allophones to learn. Nevertheless, educators focused on the local need for students to use English in Saskatchewan, whereas parents focused on the prestige and power of English as an international language. This distinction seems to reflect the broader experiences of allophone parents with respect to language learning compared to Saskatoon educators, as well as a more globally-informed understanding of the fluidity and mobility of languages resulting from the families' experiences with international migration.

With respect to the importance participants attributed to learning French in Saskatchewan, nearly all educators and parents considered that French language 
proficiency might provide employment opportunities in the students' future. However, most parents also believed that French-English bilingualism was an essential element of Canadian identity. This was seldom mentioned by educators as a reason to learn French. This distinction corroborates the results of Mady (2013), who found that allophone families were more likely than Anglophone families to equate French-English bilingualism with Canadian identity. The parents in this study also provided extrinsic (employment) and intrinsic (identity) reasons for French language learning.

Regarding language learning ability, most educators expressed the view that learning French would support the development of English proficiency for allophone learners, which has been documented in previous research (Carr, 2009). However, some teachers and principals argued that a certain baseline of English proficiency was necessary to succeed in immersion, citing the tendency for teachers to use English in their instruction and the predominance of English in the sociolinguistic context of Saskatchewan. In contrast, allophone parents were confident in their children's abilities to learn French and English concurrently, which is consistent with previous research documenting allophone families' preference for simultaneous language learning (Dagenais \& Moore, 2008). This divergence in views likely stems from the fact that many allophone parents have personal experience with simultaneous language learning, whereas virtually all teacher participants shared in their interviews that they had learned English and French sequentially.

Some educators stated that Anglophone parents were better able than allophone parents to support their children with their French learning because the former group had likely received prior French exposure. This argument is not only unsubstantiated by research, but also highly suspect in Saskatchewan, where only 5\% of the province speaks French (Statistics Canada, 2014). Furthermore, to suggest that French immersion is most suitable for students whose parents demonstrate familiarity with French is to misunderstand the purpose of the program entirely. The intent for immersion has never been to support the French practices of families who already display French language abilities. Rather, French immersion exists to teach and promote the French language throughout Canada, not only for the social and cognitive benefits attached to multilingualism, but also for reasons of national unity (Hayday, 2015; Kjolseth, 1977; Lambert \& Tucker, 1972; Lapkin, 1983; Swain \& Lapkin, 2005).

The findings of the present study demonstrate that most educators and parents believed that French immersion was a suitable program for allophone learners. Many educators asserted that allophone learners tended to be academically successful in French immersion for reasons such as prior language learning experience and support for multilingualism from the families. Nevertheless, this research also revealed diverging and unsubstantiated views on the part of some educators regarding sequential versus simultaneous language learning, as well as presumed disadvantages of allophone learners relative to their Anglophone classmates. Therefore, the authors recommend that educators continue to familiarize themselves with the research concerning the experiences of allophones in French immersion and to reflect critically on beliefs and practices that might unintentionally create obstacles for the learning of such students.

\section{The Inclusion and Exclusion of Allophone Students}

The second research question sought to examine opinions about the gatekeeping roles different stakeholders should play in determining the inclusion and exclusion of 
allophone learners. The vast majority of educators responded positively to survey items and interview questions asking whether they believed that allophone students should be included in immersion programs. Moreover, several educators mentioned a recent institutional shift toward the inclusion of allophone students in immersion, explaining that learners with diverse home languages had often been excluded in the past but that their presence in French immersion was increasingly embraced throughout the school board. However, some teachers and school administrators expressed the notion that all studentsregardless of first language - should initially be included in French immersion, but that those who are later deemed to be experiencing difficulty should be removed. The criteria upon which these enrolment decisions should be based-limited English proficiency, academic difficulties, and behavioural challenges, to name a few-were not consistent amongst participants, which corroborates the findings of Mady and Masson (2018) regarding the contradictory views of immersion principals. Most educators expressed the view that the school board should not adopt a widespread policy or practice pertaining to the inclusion of allophone students. Rather, they thought such decisions should be made on a case-by-case basis. In summary, most participants were theoretically inclusive of allophone learners, but a more nuanced analysis revealed that relatively few educators would advocate for the categorical inclusion or exclusion of such students.

The present study examined participants' beliefs regarding the gatekeeping roles educators and parents should play in French immersion programs. Most participants from both populations expressed that allophone parents should be able to select the program of study for their children, although support for this sentiment was stronger amongst parents. Most allophone parents were strongly opposed to the idea that educators should influence such decisions; all parents argued that enrolment decisions should be made exclusively by the families in question. In contrast, teachers and principals espoused a variety of views pertaining to the gatekeeping role of French immersion educators, ranging from supporting the family's choice unequivocally to overruling the decision entirely in order to exclude certain allophone students. This disagreement between educators and parents not only indicates tensions regarding the gatekeeping of French immersion, but it also signifies conflicting views regarding the suitability of such programs for allophone learners.

The present study also revealed that some educators refrained from discouraging families for fear of being reprimanded by school administrators. Thus, there is a distinction to be made between educators who truly believe French immersion is suitable for allophone students and those who oppose this view but feel stifled from influencing enrolment decisions. In light of the controversy surrounding gatekeeping practices in immersion, teachers and principals likely underreport the extent to which they discourage families from pursuing the program. Moreover, although most parent participants indicated that teachers did not discourage their children's participation in French immersion, these findings do not preclude the possibility of certain educators dissuading other allophone families from enrolling; such families would have been ineligible to participate in this study if they had been excluded from immersion.

The researchers investigated the extent to which allophone parents believed school administrators encouraged or discouraged them from enrolling their children in French immersion. Whereas no parent participants suggested that principals discouraged them from enrolling their children in French immersion, few believed administrators had encouraged them to select this program. The vast discrepancies amongst parents' experiences suggests that educators do not follow a consistent practice or policy with 
regard to the inclusion of allophone students in French immersion; the gatekeeping function of educators varies considerably from one school to the next. The absence of a sound, evidence-based policy pertaining to allophone students in French immersion inevitably leads to inconsistent and erratic practices throughout the province, based not on research but on the variable discretion of individual administrators. Therefore, the authors strongly recommend the development and implementation of a policy to ensure equitable access to French immersion for allophone learners and eliminate the arbitrary practices endemic in Saskatchewan today.

\section{Conclusion}

The present study employed a concurrent mixed-methods research design, consisting of surveys and semi-structured interviews, to explore the perspectives of educators and parents concerning the suitability of French immersion programs for allophone students in Saskatoon, Saskatchewan. This research generated several thoughtprovoking results about participants' perceptions of French immersion for allophone learners, including numerous discrepancies between the two stakeholder populations regarding the extent to which the program was considered appropriate for such learners. Nevertheless, it is important to consider certain limitations of this study. Notably, the number of survey participants is quite small compared to previous research, such as Lapkin, Macfarlane, and Vandergrift (2006). The small number of parent interview participants presents a similar limitation. Thus, the extent to which the results of this study can be extrapolated across different contexts is limited. Finally, insofar as the researchers were not permitted to recruit families who did not have children enrolled in French immersion at the time of the study, the extent to which allophone students are discouraged from enrolling or continuing in immersion remains unknown.

The above limitations notwithstanding, the present study contributes to the body of research examining allophone students in French language programs in Canada. First, the majority of French immersion teachers and principals in the school board participated in surveys and interviews, and the 43 educator interviews generated substantive results about a range of topics in immersion. Furthermore, the site of the research was itself important and heretofore unexplored with respect to allophones in immersion (Mady \& Turnbull, 2012). The urgency for such research, both in Saskatchewan and throughout the country, is especially critical, given the Government of Canada's ongoing commitment to welcome refugees nationwide (Government of Canada, 2017). The high number of refugees fleeing persecution in the United States by migrating to Canada illustrates the need for a greater focus on allophone language education policy.

With respect to avenues for future research, further attention must be given to the perceived suitability of different French language programs for allophone students, including late French immersion. Similarly, although some studies have explored the gatekeeping function of French immersion principals and Kindergarten teachers, this topic requires greater attention as it pertains to late French immersion. Researchers might also consider exploring the perspectives of teachers, principals, and parents at the secondary level. Further research analyzing policy implementation in French language programs is needed, including research on the effects of different policies and practices on allophone learners' access to French immersion (Mady \& Turnbull, 2012). Future studies should also explore the inclusion and exclusion of different student populations - such as First Nations, 
Inuit, and Métis learners - in French language programs. To this end, the authors recommend that scholars investigate such instructional programs through the lens of LangCrit, or Critical Language and Race Theory (Crump, 2014). The extent to which various minority groups are underrepresented in French immersion might be the result of practices that privilege certain ethnic and linguistic populations to the detriment of others. This concern warrants consideration from anti-racist scholars. Indeed, there might be practices in the school board that, perhaps unintentionally, exclude families of colour from immersion under the pretence of insufficient language proficiency. It is our hope that the present study might serve as a catalyst for educators and academics to further explore language instruction and policies in order to better serve increasingly diverse student populations in Saskatchewan and beyond.

\section{Acknowledgements}

We would like to thank the editors and the anonymous reviewers from the Canadian Journal of Applied Linguistics for their valuable feedback and recommendations for this manuscript. Additionally, we would like to express our gratitude to the educators and parents who participated in this study and who work tirelessly to teach and nurture all learners in their care. Finally, this research would not have been possible without the generous funding provided by the Social Sciences and Humanities Research Council of Canada (SSHRC).

Correspondence should be addressed to Stephen Davis.

Email: stephen.davis4@mail.mcgill.ca

\section{References}

Bérubé, D., \& Marinova-Todd, S. H. (2012). The development of language and reading skills in the second and third languages of multilingual children in French Immersion. International Journal of Multilingualism, 9(3), 272-293.

Bonjour SK. (2018). Locating Schools. Retrieved from https://www.bonjoursk.ca/en/education/schools

Canada Privy Council Office. (2003). The next act: New momentum for Canada's linguistic duality. Retrieved from http://publications.gc.ca/collections/Collection/CP22-682003E.pdf

Carr, W. (2007). Teaching core French in British Columbia: Teachers' perspectives. Vancouver, BC: British Columbia Association of Teachers of Modern Languages.

Carr, W. (2009). Intensive French in British Columbia: Student and parent perspectives and English as additional language (EAL) student performance. Canadian Modern Language Review, 65(5), 787-815.

Carr, W. (2013). Learning French in British Columbia: English as additional language learner and parent perspectives. In K. Arnett \& C. Mady (Eds.), Minority populations in second language education (pp. 22-37). Toronto: Multilingual Matters.

Creswell, J. W. (2014). Research design: Qualitative, quantitative, and mixed methods approaches. Thousand Oaks, CA: SAGE Publications. 
Crump, A. (2014). Introducing LangCrit: Critical language and race theory. Critical Inquiry in Language Studies, 11(3), 207-224.

Dagenais, D., \& Berron, C. (2001). Promoting multilingualism through French immersion and language maintenance in three immigrant families. Language, Culture and Curriculum, 14(2), 142-155.

Dagenais, D., \& Jacquet, M. (2000). Valorisation du multilinguisme et de l'éducation bilingue dans des familles immigrantes. Journal of International Migration and Integration, 1(4), 389-404.

Dagenais, D., \& Moore, D. (2008). Représentations des littératies plurilingues, de l'immersion en français et des dynamiques identitaires chez des parents chinois. Canadian Modern Language Review, 65(1), 11-31.

D'Almeida, E. (2006). French Education in Saskatchewan. Retrieved from https://esask.uregina.ca/entry/french_education_in_saskatchewan.jsp

Department of Canadian Heritage. (2008). Roadmap for Canada's linguistic duality 20082013: Acting for the future. Retrieved from https:/www.canada.ca/content/dam/pch/documents/services/official-languagesbilingualism/roadmap/08-13-LDL-eng.pdf

Galiev, A. (2013). Official bilingualism and immigrants: Perceptions, experiences and practices (Unpublished doctoral dissertation). University of Calgary, Calgary, Alberta, Canada.

García, O. (2002). Teaching language minorities in the United States: From bilingualism as a deficit to bilingualism as a liability. International Journal of the Sociology of Language, 155/156, 125-130.

Genesee, F., \& Lindholm-Leary, K. (2013). Two case studies of content-based language education. Journal of Immersion and Content-Based Language Education, 1(1), 3 33.

Government of Canada. (1985). Official Languages Act. Retrieved from: http://lawslois.justice.gc.ca/eng/acts/o-3.01/page-1.html\#h-1

Government of Canada. (2017). \#WelcomeRefugees: Canada resettled Syrian refugees. Retrieved from http://www.cic.gc.ca/english/refugees/welcome/index.asp

Government of Saskatchewan. (2014). Saskatchewan statistical immigration report 2012 to 2014. Retrieved from http://publications.gov.sk.ca/documents/310/933532014\%20Immigration\%20Statistical\%20Report\%20\%20July\%2020\%202016.pdf

Government of Saskatchewan. (2017). Saskatchewan language: 2016 census of Canada. Retrieved from http://publications.gov.sk.ca/documents/15/1042902016\%20Census\%20Language, \%20Mobility\%20and\%20Citizenship.pdf

Hayday, M. (2015). So they want us to learn French: Promoting and opposing bilingualism in English-speaking Canada. Vancouver, Canada: UBC Press.

Haque, E. (2012). Multiculturalism within a bilingual framework: Language, race, and belonging in Canada. Toronto, Canada: University of Toronto Press.

Izquierdo, J., \& Collins, L. (2008). The facilitative role of L1 influence in tense-aspect marking: A comparison of hispanophone and anglophone learners of French. The Modern Language Journal, 92(3), 350-368.

Johnson, R. K., \& Swain, M. (1997). Immersion education: International perspectives. New York, NY: Cambridge University Press.

Kjolseth, R. (1977). Bilingual education: For what and for whom? [Review of the books Bilingual education of children: The St. Lambert Experiment, by W. E. Lambert \& 
G. R. Tucker and Bilingual education in a binational school: A study of equal language maintenance through free alternation, by W. F. Mackay]. Language in Society, 6(2), 247-263.

Lambert, W. E., \& Tucker, G. R. (1972). Bilingual education of children: The St. Lambert experiment. Rowley, MA: Newbury House Publishers.

Lapkin, S. (1983). French immersion: The trial balloon that flew. Language and Literacy Series. Toronto, Canada: OISE Press.

Lapkin, S., MacFarlane, A., \& Vandergrift, L. (2006). Teaching French in Canada: FSL teachers' perspectives. Ottawa, Canada: Canadian Teachers' Federation.

Lindholm-Leary, K., \& Genesee, F. (2014). Student outcomes in one-way, two-way, and indigenous language immersion education. Journal of Immersion and ContentBased Language Education, 2(2), 165-180.

Lyster, R. (2008). Evolving perspectives on learning French as a second language through immersion. In D. Ayoun (Ed.), Studies in French Applied Linguistics (pp. 3-36). Amsterdam, Netherlands: John Benjamins Publishing Company.

Mady, C. J. (2003). Motivation to study and investment in studying core French in secondary school: Comparing English as a second language and Canadian-born students (Unpublished manuscript). OISE/University of Toronto, Toronto, Ontario, Canada.

Mady, C. (2007). The suitability of core French for recently arrived adolescent immigrants to Canada. Canadian Journal of Applied Linguistics/Revue canadienne de linguistique appliquée, 10(2), 177-196.

Mady, C. (2010). Motivation to study core French: Comparing recent immigrants and Canadian-born secondary school students. Canadian Journal of Education, 33(3), 564-587.

Mady, C. (2011). Moving toward inclusive French as a second official language in Canada. International Journal of Inclusive Education. doi:10.1080/13603116. 2011.580463

Mady, C. (2013). Adding languages adding benefits: Immigrant students' attitudes toward and performance in FSOL programs in Canada. In K. Arnett \& C. Mady (Eds), Minority populations in second language education: Broadening the lens from Canada (pp. 3-21). Bristol, United Kingdom: Multilingual Matters.

Mady, C. (2014). Immigrants outperform Canadian-born groups in French immersion: Examining factors that influence their achievement. International Journal of Multilingualism, (ahead-of-print), 1-14.

Mady, C. (2015). Examining immigrants' English and French proficiency in French immersion. Journal of Immersion and Content-Based Language Education, 3(2), 268-284.

Mady, C., \& Arnett, K. (2016). French as a second language teacher candidates' conceptions of allophone students and students with learning difficulties. Canadian Journal of Applied Linguistics/Revue canadienne de linguistique appliquée, 18(2), 78-95.

Mady, C., \& Black, G. (2012). Access to French as second official language programs in English-dominant Canada. Alberta Journal of Educational Research, 57(4), 498501.

Mady, C., \& Masson, M. (2018). Principals' beliefs about language learning and inclusion of English language learners in Canadian elementary French immersion programs. 
Canadian Journal of Applied Linguistics/Revue canadienne de linguistique appliquée, 21(1), 71-93.

Mady, C., \& Turnbull, M. (2010). Learning French as a second official language: Reserved for Anglophones? Canadian Journal of Educational Administration and Policy, 99, $1-23$.

Mady, C., \& Turnbull, M. (2012). Official language bilingualism for allophones in Canada: Exploring future research. TESL Canada Journal, 29(2), 131-142.

Reeves, M. (2006). French Immersion Education. Retrieved from https://esask.uregina.ca/entry/french_immersion_education.jsp

Roy, S. (2008). French immersion studies: From second-language acquisition (SLA) to social issues. Alberta Journal of Educational Research, 54(4), 396-406.

Roy, S. (2015). Discours et idéologies en immersion française. Canadian Journal of Applied Linguistics/Revue canadienne de linguistique appliquée, 18(2), 125-143.

Saskatchewan School Boards Association. (2017). School Divisions. Retrieved from: https://saskschoolboards.ca/school-divisions/

Statistics Canada. (2014). Linguistic characteristics of Canadians. Retrieved from: http://www12.statcan.ca/census-recensement/2011/as-sa/98-314-x/98-314x2011001-eng.cfm

Swain, M., \& Lapkin, S. (2005). The evolving sociopolitical context of immersion education in Canada: Some implications for program development. International Journal of Applied Linguistics, 15(2), 169-186. 